2014

\title{
Criminalization of Polygamy in Canada: Historical, Legal and Sociological Analysis
}

Washi Ahmed

Follow this and additional works at: http://digitalcommons.osgoode.yorku.ca/olsrps

\section{Recommended Citation}

Ahmed, Washi, "Criminalization of Polygamy in Canada: Historical, Legal and Sociological Analysis" (2014). Osgoode Legal Studies Research Paper Series. 7.

http://digitalcommons.osgoode.yorku.ca/olsrps/7 


\section{OSGOODE HALL LAW SCHOOL LEGAL STUDIES RESEARCH PAPER SERIES}

Research Paper No. 78

Vol. 10/ Issue. 17/ (2014)

\section{Criminalization of Polygamy in Canada: Historical, Legal and Sociological Analysis}

Washim Ahmed

Editors:

Editor-in-Chief: Carys J. Craig (Associate Dean of Research \& Institutional Relations and Associate Professor, Osgoode Hall Law School, York University, Toronto)

Production Editor: James Singh (Osgoode Hall Law School, York University, Toronto)

This paper can be downloaded free of charge from: http://ssrn.com/abstract=2508804

Further information and a collection of publications from the Osgoode Hall Law School Legal Studies Research Paper Series can be found at:

http://papers.ssrn.com/sol//JELJOUR_Results.cfm?form_name=journalbrowse\&journal_id=722488

Osgoode Legal Studies Research Paper No. 78

Vol. 10/ Issue. 17/ (2014) 


\title{
Criminalization of Polygamy in Canada: Historical, Legal and Sociological Analysis
}

\author{
Washim Ahmed
}

\begin{abstract}
:
The Canadian Criminal Code criminalizes the act of polygamy pursuant to s.290, and bigamy (another act which is similar to polygamy) pursuant to 5.293 under the assumption that such practices have an adverse impact on women and children. However, the history of the criminalization of polygamy in Canada suggests that it was enacted deliberately to marginalize a particular minority group.

This paper is divided into four chapters. Chapter I discusses the historical background of polygamy and indicates that the criminalization of polygamy in Canada was an adoption of the American legal approach to Mormonism. Chapter II analyzes the provisions of the Canadian Criminal Code and demonstrates that the criminalization of polygamy significantly limits the rights and freedoms of individuals that are protected under the Charter. It also argues that the limitation of those rights and freedoms are so severe that they cannot be justified in a free and democratic society. Chapter III discusses the social aspects of the criminalization of polygamy. It describes how prohibition on polygamy creates an adverse impact on the society and promotes inequality and discrimination in the name of equality. Chapter IV provides a summary of the benefits that can be achieved if polygamy is legalized in Canada.
\end{abstract}

\section{Keywords:}

polygamy, criminal law, family law, Canadian law, Constitutional law, Charter, s.293, s. 290, polygyny, bigamy, women, equality, inequality, justice, family, children, Mormon, FLDS, Muslim, plural marriage, sister wives, history, America, Canadian criminal code

\author{
Author(s): \\ Washim Ahmed \\ Osgoode Hall Law School \\ York University, Toronto \\ E: mdahmed@osgoode.yorku.ca
}




\section{Criminalization of}

\section{Polygamy in Canada}

Historical, Legal and Sociological Analysis

Washim Ahmed, LL.B, (America Bangladesh University) B.A (Carleton University), LL.M (Current, Osgoode Hall Law School). 


\section{Context of the Written Work}

This submitted work is an Honour's Research Essay that was written by Washim Ahmed under the supervision of Professor Melanie Adrian and Tara Ashtakala as part of his degree requirements for BA in Law, concentration in Policy and Government under the Department of Law and Legal Studies, Carleton University. It was completed during the summer term (MayAugust) of 2013. 


\section{Preface}

In every society, marriage is viewed as one of the most important events in a person's life. Marriage is seen as part of the natural progression of life course for both men and women. ${ }^{1}$ It is almost impossible to imagine a society without marriage, due to its significance in human livelihood and social activity. While there is no question of the importance and significance of marriage, it is highly debatable how many times people should be allowed to get married. This paper primarily focuses on this debate, and takes a position in favor of polygamy.

There are various biological, legal, and sociological definitions of polygamy. For the intents and purposes of this paper, polygamy shall be defined as a relationship in which more than two partners are involved. ${ }^{2}$ Although, both men and women might practice polygamy, it is predominantly characterized as a family system in which men take multiple wives. ${ }^{3}$ This patriarchal system is also known as polygyny. ${ }^{4}$ Polyandry, on the other hand, refers to situations in which women take on multiple husbands. ${ }^{5}$ In this paper, the word "polygamy" is used to refer to both polygyny and polyandry, since this is gender-neutral terminology. However, in few instances, this paper explicitly uses the word polygyny and polyandry to specify the subject of discussion. This paper does not take a favor the legalization of polygyny over polyandry, or vice

\footnotetext{
${ }^{1}$ Elizabeth Peters, Claire M. Kamp Dus, Marriage and Family: Perspectives and Complexities (New York: Columbia University Press, 2009) at 4.

${ }^{2}$ Miriam Koktvedgaard Zeitzen, Polygamy: A Cross-Cultural Analysis (Oxford: Berg Publisher, 2008$)$ at 3.

${ }^{3}$ Bourdelois, Béatrice, Mariage polygamique et droit positif français (Paris: GLN Joly Ed, 1993) at 3-4.

${ }^{4}$ Alean Al-Krenawi, John R. Graham, "A Comparison of Family Functioning, Life and Marital Satisfaction, and Mental Health of Women in Polygamous and Monogamous Marriages”, (2006) 52 IJSP 5.

5 Amy J. Kaufman, "Polygamous Marriages in Canada" (2005) 21 Can J Fam L 315.
} 
versa. Rather, this paper leaves it to policy makers to decide which type of polygamy should be legalized, and how the legal and policy framework should be.

Currently, the Canadian Criminal Code criminalizes the act of polygamy pursuant to s.290, and bigamy (another act which is similar to polygamy) pursuant to s.293. The offense of bigamy involves participating in a legal marriage ceremony while already married, or with someone who is known to be married. On the other hand, polygamy is concerned with the status of having more than one spouse or being in a conjugal union with more than one person simultaneously instead of focusing on "marriage" per se. ${ }^{6}$ The distinction between polygamy and bigamy will be discussed further in upcoming sections. Both offenses have been criminalized for more than a hundred years in Canada.

The debate concerning the legalization of polygamy in Canada did not received a strong public attention until a religious minority group called $\mathrm{FLDS}^{7}$ Mormons of Bountiful, British Columbia started openly practicing it. While many countries where polygamy has been traditionally practiced attempted to prohibit polygamy, a number of Western countries including the United States and Canada have been facing significant challenges in upholding their prohibition on this practice. ${ }^{8}$ Particularly, after the introduction of the Canadian Charter of Rights and Freedoms and the legalization of same-sex marriage in Canada, a serious concern has been raised among many academics, social workers, and open-minded Canadians, whether or not polygamy should be legalized as well. The question has been raised "How does a selfconsciously modern, liberal society continue to criminalize a form of marriage that has existed

\footnotetext{
${ }^{6}$ Samuel Chapman, Polygamy, Bigamy and Human Rights Law (United States: Xlibris Corporation 2001$)$ at 18.

${ }^{7}$ Fundamentalist Latter-Day Saint, which is a particular branch of Mormonism.

${ }^{8}$ Angela Campbell, How Have Policy Approaches to Polygamy Responded to Women's Experiences and Rights? An International, Comparative Analysis: Final Report for Status of Women Canada" (Ottawa: Status of Women Canada, 2005). <SSRN: http://ssrn.com/abstract=1360230 or http://dx.doi.org/10.2139/ssrn.1360230>.
} 
throughout the world for millennia, when it has at the same time legalized a completely new form of marriage between same-sex couples?"9 Moreover, although polygamy has been criminalized for more than a century and there are strict punishments attached to this offense, law enforcement agencies are often reluctant in applying the criminal provision out of the fear that the provision will be challenged in the court and declared invalid based on the rights that the Charter guarantees all Canadians. ${ }^{10}$

This paper theorizes that the criminalization of polygamy infringes on the rights and freedoms of individuals that are guaranteed by the Charter and that the infringements may not be justified in a free and democratic society. A center point of discussion of this paper is the development of Mormonism in the United States and Canada. It gives particular attention to FLDS Mormonism when analyzing the breach of Charter due to the significance of polygamy in Mormonism. Although Islamic polygamy is mentioned a few times, in this paper does not give much attention to it due to the fact that polygamy is a fundamental tenet of Mormonism whereas Islam allows it with some strict conditions, and discourages it in some instances. A justified discussion of Islamic polygamy must include an elaboration of those conditions, which is beyond the scope of this essay.

This paper analyzes the credibility of the predominant narrative that polygamy has been criminalized under the Canadian Criminal Code due to its adverse impact on women and children. After a historical, legal, and social analysis of polygamy, this paper posits the thesis: although it has been argued that the criminalization of polygamy is intended to protect women and children against inequality and discrimination and ensure better lives for them, the history of

\footnotetext{
${ }^{9}$ Neil Anderson, "Polygamy in Canada: a Case of Double Standard" The Guardian (30 November 2011) http://www.theguardian.com/commentisfree/belief/2011/nov/30/heterosexuality-canada-law-monogamy-polygamy. ${ }^{10}$ Kaufman supra note 5 at 2.
} 
criminalizing polygamy suggests that it was deliberately enacted to subjugate a particular minority group and it is a systematic oppression on women and children, and that it has an adverse impact on the society as a whole. Furthermore, this papers shows that the criminalization of polygamy violates Charter-protected rights and freedoms of individuals that cannot be justified in a free and democratic society, and in order to ensure that women and children in polygamous societies live better lives, polygamy should be legalized.

In doing so, this paper is divided into four chapters. Chapter I discusses the historical background of polygamy. In this chapter, it is shown that the criminalization of polygamy in Canada was an adoption of the American legal approach to Mormonism and their religious practices. Chapter II provides an analysis of the laws that criminalizes polygamy in Canada. This chapter demonstrates that the criminalization of polygamy significantly limits individual's rights and freedoms that are protected under the Charter. It also argues that the breach of those rights and freedoms are so severe that they cannot be justified in a free and democratic society. Chapter III discusses the social aspects of the criminalization of polygamy. It describes how prohibition on polygamy creates an adverse impact on the society and promotes inequality and discrimination in the name of equality. Chapter IV provides a summary of the benefits that can be achieved if polygamy is legalized in Canada.

\section{Chapter 1}

\section{Historical Background of Criminalization of Polygamy:}


Polygamy has been criminalized in Canada since the beginning of The Canadian Criminal Code, although there were no polygamists in Canada at that time. ${ }^{11}$ It has been argued that Canadian prohibition of polygamy was strongly influenced by $19^{\text {th }}$ century's American socio-legal and political development that was intended to subjugate a particular minority religious group called the Mormons. Mormonism is a particular interpretation of Christianity founded by Joseph Smith during the first quarter of nineteenth century. Polygamy is one of the fundamental tenets of Mormonism although it is strongly condemned by the mainstream Christianity and Judaism. An important point should be noted that although Mormonism started with a mandate to reestablish Biblical traditions including polygamy and included polygamy as one of its fundamental tenets, not all Mormons practice polygamy nowadays. The largest branch of Mormonism that upholds the Mormon traditional practices of polygamy is known as Fundamentalist Latter Day Saints. The details of the development of the Mormon faith and the polygamous practices will be discussed in upcoming sections.

The Mormons have a long history of being prosecuted for religious reasons due to their practices of polygamy in the United States. Over time, due to the development of Mormon Church and their dominance in the Utah region the American Congress had taken many steps to hinder the growth of Mormonism and limit their religious freedom by criminalizing their practices of polygamy. While, it has been often stated by many critics of the prohibition of polygamy that Canadian criminalization of polygamy is identical to the United State's prohibition in terms of its objectives, recently the Supreme Court of British Columbia rejected this argument. In a recent case, Reference re: Section 293 of the Criminal Code of Canada, ${ }^{12}$ in

\footnotetext{
${ }^{11}$ Although there were Mormons immigrants in south-western Alberta, they did not come with their polygamous family.

${ }^{12}$ Reference re: Section 293 of the Criminal Code of Canada, 2011 BCSC 1588.
} 
which the province, British Columbia asked the Court to declare whether the criminalization of polygamy is consistent with the freedoms guaranteed to all Canadians by the Canadian Charter of Rights and Freedoms, the Court denied any infringement of freedom of religion based on the legislative history of the s.293. ${ }^{13}$ The court stated that s.293 does not and was not intended to infringe on the religious freedoms of Mormons that were granted by the Charter, since this provision was introduced in the Canadian Criminal Code before Charles Ora Cardand (the first Mormon immigrant) and his followers settled in Canada. ${ }^{14}$ The court concluded that the purpose of the criminal provision was not intended to prohibit any of Mormon's religious beliefs or practices, rather, the harms, which were associated to the practice of polygamy concerned the lawmakers to prohibit such practices. The purpose of the criminal provision was to secure the monogamous institution of marriage, which is embraced by Christianity and has a root in secular Greco-Roman society. ${ }^{15}$ Interestingly, the court was able to acknowledge the sectarian purpose of the criminalization of polygamy, which is to protect the Judeo-Christian monogamous institution of marriage. However, the court failed to recognize the inherent discriminative purpose of the criminalization which is to limit the rights and freedoms of ethnic and religious minority groups such as Mormon, Muslims and Aboriginals. Therefore, it has become extremely important to re-examine the history of the criminalization. However, before discussing polygamy, it is also important to analyze the historical root of the concept and practice of monogamous marriage since the criminalization of polygamy is often justified on the grounds of protection of the monogamous institution of marriage. ${ }^{16}$

\footnotetext{
13 Ibid at 1 .

${ }^{14}$ Ibid at 854.

${ }^{15}$ Ibid at 903-904.

${ }^{16}$ Nicholas Bala, "Why Canada's Prohibition of Polygamy Is Constitutionally Valid and Sound Social Policy," (2009) 25 Can J Fam L 165.
} 
Monogamous marriage has a long been rooted in a Judeo-Christian tradition that started in the thirteenth century. The common law definition of marriage was solely based on the Christian understanding of marriage. Despite the fact that both Old and New Testaments do not condemn polygamy, the main branches of Christianity and Judaism rejected polygamy as inconsistent with the ideal of marriage as a love-based partnership of equals. ${ }^{17}$ Polygamy was acceptable in Judaism and Early Christianity although it was prohibited under Roman law. However, by the time the Christian churches came into existence, polygamy was already abandoned by Jews. ${ }^{18}$ Moreover, in the Early Christian writings it was strongly condemned by prominent writers such as Irenaeus, Augustine and Tertullian. By the sixteenth century, it was officially rejected by the Catholic Church from the Council of Trent. The Church felt it necessary to proclaim: "If anyone says that it is lawful for Christians to have several wives at the same time, and that it is not forbidden by any divine law, let him be anathema". ${ }^{19}$ Canadian monogamous marriage has a long root in the Judeo-Christian tradition, ${ }^{20}$ which shaped the common law definition of marriage when Canada adopted it when it entered into the Confederation. As a result, the Judeo-Christian traditional definition of marriage was valid in Canada until it was challenged in Hyde v Hyde in $1866 .^{21}$

The history of criminalizing polygamy in Canada can be traced back to the legal development of the United States during the $19^{\text {th }}$ century. Polygamy has always been illegal in the Unites States. However, the responsibility to prohibit such a practice was left with the States,

\footnotetext{
${ }^{17} \mathrm{Ibid}$.

${ }^{18}$ Joyce George, Christian Marriage: An Historical and Doctrinal Study (Maryland: Sheed and Ward Books,2007) at 560.

${ }^{19}$ A.P Percival, Roman Schism Illustrated from the record of the Catholic Church (London: Gilbert and Rivington Printers, 1836) at 327.

${ }^{20}$ Reference re: Section 293 Supra note 12.

${ }^{21}$ Hyde v Hyde [1866] 1 LRP \& D 130.
} 


\section{Page 10 of 64}

not the national Congress. ${ }^{22}$ The first time the US Congress responded to the polygamy issue was during the second half of the $19^{\text {th }}$ century when the Latter Day Saints (LDS) Church was established to uphold the Mormon polygamous marriages. ${ }^{23}$

Mormonism was founded by Joseph Smith in the first half of the $19^{\text {th }}$ century in Western New York. In 1831, Smith founded the Mormon Church (also known as the Church of Jesus Christ of Latter-day Saints or LDS Church) and claimed to have received revelation ${ }^{24}$ with the authority to restore plural marriages on earth. ${ }^{25} \mathrm{He}$ claimed that he was given the authority to practice "celestial marriage" by the same God who gave Abraham the authority to take his handmaid, Hagar, as a wife to produce righteous progeny. ${ }^{26}$ Despite his claims of authority, Smith never practiced polygamy very openly and it was not until 1844 when Smith was assassinated in Illinois, many Church leaders and his followers came to know about the revelation and his polygamous practices. ${ }^{27}$ In 1852, the LDS Church declared polygamy as a divine decree and a way to secure a high position in heaven. The early leader of the Mormon Church Brigham Young declared that a man's righteousness before God depends on the size of the family that he supports. ${ }^{28}$ Despite this declaration, only 15 to 20 percent of early members of LDS church adopted polygamy ${ }^{29}$ and it was not until 1876 when polygamy became one of the fundamental tenets of Mormonism and was included within the doctrines of salvation and the

\footnotetext{
${ }^{22}$ Shayna M. Sigman, "Everything Lawyers Know About Polygamy Is Wrong” (2006)16 Cornell JL \& Pub Pol'y 101.

${ }^{23}$ Ibid.

${ }^{24}$ The Doctrine and Covenants of the Church of the Latter Day Saints: Carefully Selected from the Revelations of God also known as the Doctrine and Covenants is the most sacred scriptures of Mormonism. Section 132 of the Doctrine and Covenants addresses the question of polygamy.

25 Janet Bennion, Polygamy in Primetime: Media, Gender and Politics in Mormon Fundamentalism,

${ }^{26}$ Ibid.

${ }^{27}$ Sarah Barringer Gordon, The Mormon Question:Polygamy and Constitutional Conflict in Ninteenth Century America (Chapel Hill: University of North Carolina Press, 2002) at 22-23.

${ }^{28}$ Bennion,Supra note 25 at 24.

${ }^{29}$ Quinn, D Mocheal, "Mormon Women Have Had the Priesthood since 1843" In Maxine Hanks, eds, Women and Authority: Re-Emerging Mormon Feminism (Salt lake City: Signature Books, 1992).
} 
covenants. $^{30}$ Nevertheless, this declaration was not consistent with the traditional value of mainstream or orthodox Christianity and Judaism, thus Mormons started facing resistance and violence from non-Mormon Christians who lived nearby. ${ }^{31}$

Eventually, Mormonism became a dominant political force in some of the States, and the Mormon leader Brigham Young became the governor of Utah. With the development of their dominance in the State of Utah, Mormons started refusing the separation between state and church and federal legislative authority over the territory. Consequently, they became isolated not only religiously, but also politically, socially, and economically, which eventually led them to the Mormon War of $1857 .{ }^{32}$

Over the course of a thirty year of long battle, Congress passed many legislative acts to hinder the growth of Mormonism and their practices of polygamy. The first attempt was the enactment of Morill Anti-Bigamy Act ${ }^{33}$ in which the practices of polygamy were banned in all territories. The Act criminalized the practices of bigamy, which it defined as when one person with a "husband or wife living" marries another person within the territory over which the United States has jurisdiction. ${ }^{34}$ It further barred any religious charitable organization from owning any property in Utah worth more than $\$ 50,000$ as well as forfeiture any property above $\$ 50,000 .^{35}$ Twelve years after the Morill Anti-Bigamy Act was enacted, ${ }^{36}$ the first judicial

\footnotetext{
${ }^{30}$ Ibid.

${ }^{31}$ David L. Chambers, "Polygamy and Same-sex Marriage" (1997) 26 Hofstra LR 53.

${ }^{32}$ Sigman supra note 22 at 3.

${ }^{33}$ Morill Anti-Bigamy Act, ch. 126, 12 Stat 501 (1862).

${ }^{34}$ Amy J. Kufman, Martha Bailey, Polygamy in the Monogamous World (California: Praeger, 2010 ) at 86.

${ }^{35}$ Ibid.

${ }^{36}$ The differences between polygamy and bigamy is not quit clear in American Jurisprudences. According to Black's Law dictionary bigamy is defined as "the criminal offense of willfully and knowingly contracting a second Q marriage (or going through the form of a second marriage) while the first marriage, to the knowledge of the offender, is still subsisting and undissolved". Whereas, Polygamy is defined as "the offense of having several wives or husbands at the same time, or more than one wife or husband at the same time". Nevertheless, it can be said that the distinction is when a person is legally married to more than one person is subjected to the offenses of bigamy whereas, polygamy is the plurality of wives or partners regardless of whether they are legally married or not. See,
} 
response to the question of polygamy was recorded in 1974 in the pioneer case US $v$ Reynolds ${ }^{37}$ in which George Reynolds, a loyal member of LDS church was convicted on the charge of polygamy. The main legal question before the US Supreme Court was whether he should be convicted with criminal charges due to his religious belief about polygamy. ${ }^{38}$ The court also rejected the jurisdictional question but only considered whether Mormon polygamy is a true religious requirement and protected under the First Amendment. ${ }^{39}$ The court found it to be a true religious requirement. The court also argued that the First Amendment protects religious belief but not the actions that results from it particularly when the action(s) found to be violating "social orders or subversive of good order". ${ }^{40}$ In coming to this verdict, the court stated that such a result is unacceptable since it undermines the rule of law saying "to permit this would be to make the professed doctrines of religious belief superior to the law of the land". 41

Although, the law that criminalized polygamy had been passed, and the constitutional validity of the law had been confirmed, it was still difficult to stop such practices due to internal resistance and technical difficulties, such as unregistered marriage and lack of evidence of cohabitation. Congress realized that Mormons often do not seek marriage licenses, so that they cannot be charged for practicing polygamy and their illegitimate wives and children (according to the Congress) can inherit their property, no matter which marriage they come from. Moreover, there was a strong resistance within the state of Utah by women living in polygamous marriages which made the Morill Act impractical and difficult to apply. To address this socio-legal gap,

The Law Dictionary, online ed, sub verbo "bigamy" < http://thelawdictionary.org/bigamy/\#ixzz2bha1Sx11>. On the other hand, the distinction between polygamy and bigamy is little clearer in Canada than the US. This will be discussed in coming paragraphs.

${ }^{37}$ United States v. Reynolds, 345 U.S. 1 (1953).

${ }^{38}$ Kufman supra note 34 at 87.

${ }^{39}$ United States v. Reynolds, 1 Utah 319 (1876) 145, 162.

${ }^{40}$ Ibid.

${ }^{41}$ Ibid. 
Congress passed the Edmunds Act in which they tried to show the "erosion of sympathy"42 to women who resisted the Moril Act and who expressed their willing to live in polygamy by prohibiting any kind of cohabitation. ${ }^{43}$ Moreover, they passed another piece of legislation called Edmunds-Tucker Act ${ }^{44}$ in which Congress excluded polygamist from jury services and political office and declared that in order to be eligible to vote, men have to take an oath that they were not cohabiting with more than one woman.

To deal with the difficult situation LDS President Willson Woodruff issued a manifesto in 1890 in which he prohibited polygamy for the followers of the church. ${ }^{45}$ He justified his decision by claiming that he had received a revelation that the law had been fulfilled and it was now the time for the church to abandon polygamy. ${ }^{46}$ However, polygamy was continued among many of the members of the Church. ${ }^{47}$ Another church leader and Mormon Prophet, Joseph F. Smith, issued another manifesto to eradicate polygamy for all Mormons. ${ }^{48}$ However, these manifestos were rejected by many of the followers of the church, who later separated from the Church and formed one of the prominent branches of Mormonism known as Fundamentalist Latter Day Saints (FLDS). These fundamentalist Mormons believed that there was a political interest behind the issuance of those manifestos and the holy covenants were being manipulated by the Church for political gain. ${ }^{49}$ This political reconciliation is also evident in academic literatures. According to Arrington, the LDS church and the government came to an agreement prior to the issuance of the manifesto that Utah would be granted statehood in exchange for

\footnotetext{
${ }^{42}$ Gordon supra note 27 at 147.

${ }^{43}$ Chambers supra note 31 at 7.

${ }^{44}$ Edmunds-Tucker Act, ch. 397, 24, 24 Stat 635, 639-40 (1887) (repealed 1978).

${ }^{45}$ Bennion, supra note 28 at 24.

${ }^{46}$ Ibid at 25.

${ }^{47}$ Ibid.

${ }^{48}$ Ibid.

${ }^{49}$ Ibid
} 


\section{Page 14 of 64}

abandoning polygamy, the formation of The United Order and Mormon Political Party. ${ }^{50}$ Nevertheless, the followers of the FLDS church still claims that the LDS church has no legitimacy and lost its authority to receive revelation from God when it abandoned polygamy during the presidency of Woodruff. ${ }^{51}$

An important point should be noted: Although religious and political conflicts were the main contributing factors that influenced Congress to criminalize Mormon polygamy, many Americans also viewed polygamy as a way of enslaving women, especially, after the eradication of slavery in post-Civil War America. ${ }^{52}$ Nonetheless, it can still be concluded that the main purpose of this legal development was to hinder the growth of a particular minority religious group, prevent them from practicing their religion, and make them politically week.

This American legal development strongly influenced the criminalization of polygamy in Canada, as Susan Drummond points out and "Canadian anti-polygamy legislation arose directly out of cross-border pressure from the American government to follow a set of statutory persecutions enacted over a period of thirty years against fundamentalist Mormons." ${ }^{, 53}$ Canadian history of polygamy can be traced back to the immigration of Charles Ora Cardand a polygamist Mormon (who escaped from custody on charges of polygamy) and his followers who settled in south-western Alberta in $1886 .^{54}$ Their immigration was accepted by the Canadian government due to the increasing demand of good farmers to bring large tracts of western land under cultivation, even though the immigration was illegal according to the US authority. ${ }^{55}$ However, most early Mormons immigrated to Canada with one wife since it was not clear whether they

\footnotetext{
${ }^{50}$ Leonard Arrington, "Religion and Economics in Modern History" (1961) 3 BYU Studies 15 at 31-32.

${ }^{51}$ Bennion supra note 28 at 25

${ }^{52}$ Kufman supra note 34 at 80.

${ }^{53}$ Susan Drummond, "Polygamy's Inscrutable Criminal Mischief”, (2009) 47 Osgoode Hall LJ 317 at 29.

${ }^{54}$ Jessie L. Embry, Mormon Polygamous Families: Life in the Principle (Salt Lake City: University of Utah Press) at 24.

${ }^{55}$ Kufman supra note 34 at 121.
} 
would be able to practice polygamy. ${ }^{56}$ This is due to the fact that in 1841 , Canada, as a British colony, had already adopted an English anti-bigamy colonial legislation which made it an offense for someone already married to marry someone else, regardless of where the marriage took place. ${ }^{57}$ It is important to note that Canadian criminalization of bigamy and polygamy are totally separate historical legal developments that had separate objectives and procedures. Polygamy was criminalized 50 years after the criminalization of bigamy. While bigamy legislation was a colonial statute passed by British Parliament without targeting any particular groups such as Mormons, the criminalization of polygamy was a Canadian legislation passed by the Parliament of Canada targeting Mormons. This is evident from the fact that the original criminal provision of the Canadian Criminal Code 1892 made specific reference to Mormon "spiritual or plural marriage",58 which was removed from the Canadian Criminal Code in 1954 by the advocacy of two Canadian Mormons, one of which was John Blackmore, a member of Canadian Parliament and an excommunicated member of FLDS Church. ${ }^{59}$ Furthermore, the Law Reform Commission of Canada explains the differences between polygamy and monogamy in this way:

...Polygamy consists in the maintaining of conjugal relations by more than two persons. When the result of such relations is to form a single matrimonial or family entity with the spouses, this regarded as polygamous marriage... The maintaining of more than one monogamous union by the same person corresponds with the popular notions of bigamy... in legal terms, however, [polygamy and bigamy] have a more specific meaning.

\footnotetext{
56 Jessie L. Embry, "Two Legal Wives: Mormon Polygamy in Canada, The United States and Mexico" in The Mormon Presence in Canada, ed. Brigham Y. Card et al (Edmonton, Ab: University of Alberta Press, 1990) at 170-183,176.

${ }^{57}$ An Act for Consolidating and Amending the Statute in this Province relative to Offences Against the Person, Statues of the Province of Canada 1841, c.27, s 22.

${ }^{58}$ Canadian Criminal Code SC 1892, c29, s 278.

${ }^{59}$ Daphne Bramham, The Secret Lives of Saints: Child Brides and Lost Boys in Canada's Polygamous Mormon Sect (Toronto: Random House Canada, 2008) at 47-49.
} 
In particular bigamy, which defined in relation to the legal institutions of marriage, is distinguished from polygamy by the requirement of formal marital ties. ${ }^{60}$

The reason behind emphasizing this distinction is because in the case Reference re: section 293, the Supreme Court of British Columbia failed to take this distinction into consideration and erroneously argued that the criminal provision was introduced in the Canadian Criminal Code before Charles Ora Cardand and his Mormon followers settled in Canada. ${ }^{61}$ However, history suggests that this statement refers to the English colonial bigamy legislation, not the provision of Canadian Criminal Code regarding polygamy. Moreover, the court argued that the purpose of the criminal provision was not intended to prohibit Mormon's religious belief or practices but, the harms associated with this practice. ${ }^{62}$ According to the court, the purpose of the criminal provision was to secure monogamous marriage, which is embraced by Christianity and has a root in secular Greco-Roman society. ${ }^{63}$ While there is no doubt that the criminalization was enacted to protect the institution of marriage, particular reference to Mormon "spiritual marriage" in the original Canadian Criminal Code seems to suggest that the purpose was to adopt the US legal development and hinder the growth of Mormonism and their polygamous marriage. Meanwhile, Canadian legislators seized the opportunity to criminalize polygamy without encountering any of the resistance that the United States' legislators encountered.

The confirmation of this argument can also be found in the working paper of the Law Reform Commission of Canada:

There is no question that at this time Canadian legislation fell under the influence of the American law which was trying by means of the criminal law to stamp out a

\footnotetext{
${ }^{60}$ Law Reform Commission of Canada, Bigamy, Working Paper No. 42 (Ottawa: Law Reform Commission of Canada, 1985) at 13.

${ }^{61}$ Reference re: Section 293 supra note 12.

${ }^{62}$ Ibid at 903-904.

${ }^{63}$ Ibid.
} 
resurgence of the practice of polygamy among members of the Mormon community, especially in the state of Utah. ${ }^{64}$

Early criminalization of polygamy was intended to implement the American legal ideology in Canada and hinder the growth of Mormonism. ${ }^{65}$ Therefore, it can be stated that the Canadian and American prohibitions on polygamy are identical in respect to their objectives, which is to subjugate a minority group Susan Drummond points this out, stating, "this disconcerting history supports the idea that the polygamy provision was crafted as a means of disciplining and colonizing socially and politically marginal groups" ${ }^{, 66}$ for a sectarian purpose.

\section{Chapter 2}

\section{Legal Approach to the Criminalization of Polygamy}

In this section, the legal analysis of the criminalization of polygamy is conducted, based primarily on the legal principles articulated in The Canadian Charter of Rights and Freedoms. It is almost impossible to argue in favor of the legalization of polygamy without discussing the Charter, due to its supremacy over any law of Canada. Even though Canada is a federal state that has different levels of jurisdiction, the Charter is the overarching legal mechanism. Therefore, all laws, including the Canadian Criminal Code, must be consistent with its fundamental values.

There are five provisions of the Charter that are relevant to this discussion. These provisions are s.2 (a), s.2 (b), s.2 (d), s.7 and s.15. These sections will be analyzed and discussed in detail in coming section. In examining whether or not these provisions are violated by the criminalization, relevant legal principles shall be discussed from various jurisprudences and legal

\footnotetext{
${ }^{64}$ Ibid.

${ }^{65}$ Kaufman supra note 5

${ }^{66}$ Drummond supra 53 at 369.
} 
literature. However, before moving to the next section, it is important to give an overview of the polygamy and bigamy legislation in Canada.

Overview of the Law:

As indicated earlier, the prohibition of bigamy and polygamy are different offenses in Canada. Bigamy is defined in section 290 of the Canadian Criminal Code and the punishment is defined in section 291, whereas the offense of polygamy is defined in section 293. Bigamy is defined as follows:

290. (1) Everyone commits bigamy who

(a) in Canada,

(i) being married, goes through a form of marriage with another person,

(ii) knowing that another person is married, goes through a form of marriage with that person, or

(iii) on the same day or simultaneously, goes through a form of marriage with more than one person; or

(b) being a Canadian citizen resident in Canada, leaves Canada with intent to do anything mentioned in subparagraphs (a)(i) to (iii) and, pursuant thereto, does outside Canada anything mentioned in those subparagraphs in circumstances mentioned therein. ${ }^{67}$

The defenses of bigamy are articulated in s. 290. (2) as follows:

(2) No person commits bigamy by going through a form of marriage if

(a) that person in good faith and on reasonable grounds believes that his spouse is dead;

(b) the spouse of that person has been continuously absent from him for seven years immediately preceding the time when he goes through the form of marriage, unless he knew that his spouse was alive at any time during those seven years;

(c) that person has been divorced from the bond of the first marriage; or

(d) the former marriage has been declared void by a court of competent jurisdiction. Incompetency no defense

(3) Where a person is alleged to have committed bigamy, it is not a defense that the parties would, if unmarried, have been incompetent to contract marriage under the law of the place where the offence is alleged to have been committed.

${ }^{67}$ Criminal Code, RSC 1985, c C-46. 
It should be noted that a bigamous marriage is considered to be a legal marriage unless the accused demonstrates that the marriage is invalid and conviction of bigamy does not necessarily nullify a marriage. ${ }^{68}$

On the other hand, polygamy and punishment for its practices are defined under s.293 of the Canadian Criminal Code. It reads as follows:

293. (1) Everyone who

(a) practices or enters into or in any manner agrees or consents to practice or enter into

(i) any form of polygamy, or

(ii) any kind of conjugal union with more than one person at the same time, whether or not it is by law recognized as a binding form of marriage, or

(b) celebrates, assists or is a party to a rite, ceremony, contract or consent that purports to sanction a relationship mentioned in subparagraph (a)(i) or (ii), is guilty of an indictable offense and liable to imprisonment for a term not exceeding five years.

Evidence in case of polygamy

(2) Where an accused is charged with an offenseoffence under this section, no averment or proof of the method by which the alleged relationship was entered into, agreed to or consented to is necessary in the indictment or on the trial of the accused, nor is it necessary on the trial to prove that the persons who are alleged to have entered into the relationship had or intended to have sexual intercourse.

An important point to be noted is that there are no grounds of defense given to an accused person under this provision, as they are given for bigamy under s.290. In addition, the wording "everyone" includes every single legal person, regardless of gender, who enters not only into a polygamous relationship, but also in any kind of conjugal relationship in which more than one person is involved at the same time. Furthermore, the wording also includes all the people associated with such a practice, including the person who celebrates, assists, or is a party with a rite, ceremony, contract, or consent that purports to sanction a relationship.

Although polygamy is not explicitly mentioned as an absolute liability offense, it can be argued that the practical implication of the wording and the broadness of the provision are similar to an absolute liability offense. This is due to the fact that there is no scope of defense

${ }^{68}$ Criminal Code, s.290 4\&5. 
articulated in the provision. Neither any evidence of a polygamous relationship nor consent of one of the spouses is required in order to convict an individual under s.293. Moreover, it is also not required to prove that the individuals involved in polygamy have any intention to have sexual intercourse or any other marital relationships. While in the bigamy provision, the issue of mensrea $^{69}$ is articulated in the defense section, it is not mentioned anywhere in respect to polygamy. Therefore, it implies that as long as someone is found to be living with more than one individual at a time, it is sufficient to convict him or her for the indictable offense of polygamy, and the convicted person has no way to defend him or herself against the conviction unless it can be proven that he or she was not, in fact, living with more than one person. This is similar to an absolute liability offense in which no mens rea is required, and just being found involved with the offense is sufficient for the conviction. ${ }^{70}$ An example of an absolute liability offense such as parking offense could be helpful in clarifying this point. In parking related offenses, as long as a vehicle is found parked in a restricted area, no further evidence is necessary to convict the owner of the vehicle. Nevertheless, the legal consequence of this prohibition will be discussed in detail in the coming sections.

\section{Polygamy and Charter:}

The Canadian Constitution includes the Canadian Charter of Rights and Freedoms, which gives everyone residing in Canada rights and freedoms and protects them from unjustified government interference. The Canadian Charter of Rights and Freedoms is a part of the Canadian Constitution and any law or statute enacted by any level of government must be

\footnotetext{
${ }^{69}$ (menz-ray-ah) The mental component of criminal liability. To be guilty of most crimes, a defendant must have committed the criminal act in a certain mental state (the mens rea). The mens rea of robbery, for example, is the intent to permanently deprive the owner of his property. See, Legal Information Institute (August 19, 2010), Online: Cornel University Law School, <http://www.law.cornell.edu/wex/mens_rea>.

${ }^{70} R v$ City of Sault Ste-Marie [1978] 2 SCR 1299.
} 
consistent with its fundamental values. S.293 of the Canadian Criminal Code violates the constitutional rights and freedoms of Canadian citizens in five ways; (1) it infringes on the freedom of religion which is protected under s. 2 (a) of the Charter by purposely depriving the members of a religious minority group from their right to exercise a fundamental aspect of their religion; (2) this criminal provision intrudes on an individual's freedom of expression which is covered by s. 2 (b) of the Charter; (3) it violates s.2(d) of the Charter by preventing individuals from formulating a valid marital association and expressing their relationship in public; (4), the criminalization engages the life, liberty and security interests of an individual which are protected under s. 7 of the Charter; (5), s. 293 deprives everyone from the equal benefits and opportunity of law which are guaranteed by s.15 of the Charter.

\section{Freedom of Religion:}

Section 2(a) of the Charter gives "everyone" the "freedom of religion and conscience".

The freedom of religion recognizes and protects sincere beliefs and practices that connect an individual with his or her divinity. In $R v$ Big M Drug Mart, freedom of religion was defined as

"The essence of the concept of freedom of religion is the right to entertain such religious beliefs as a person chooses, the right to declare religious beliefs openly and without fear of hindrance or reprisal, and the right to manifest religious belief by worship and practice or by teaching and dissemination." 71

A legislation can infringe on constitutional rights and freedoms in two ways; either by purpose or by effect. ${ }^{72}$ The Supreme Court of Canada clarified in $R v$ Big M Drug Mart that

\footnotetext{
${ }^{71} R$ v Big M Drug Mart Ltd.,[1985] 1 SCR 295 at 336.

${ }^{72}$ All legislation is animated by an object the legislature intends to achieve. This object is realized through the impact produced by the operation and application of the legislation. Purpose and effect respectively, in the sense
} 
justification under section 1 is considered when the violation of the Charter is due to the effect of the legislation. But when legislation is intended to violate one of the Charter's protected rights of an individual or group, there is no justification under section $1 .{ }^{73}$ In $R v$ Big M Drug Mart Ltd, Big M Drug Mart was charged with unlawfully carrying on the sale of goods on a Sunday contrary to the Lord's Day Act. However, in defense of the charge, the respondent challenged the constitutionality of the Lord's Day Act on the bases of s.2 (a), freedom of religion. The Supreme Court of Canada explained how breaches of s.2 (a) occur. ${ }^{74}$ The court first described freedom as "the absence of coercion or constraint. If a person is compelled by the state or the will of another to a course of action or inaction which he would not otherwise have chosen, he is not acting of his own volition and he cannot be said to be truly free" ${ }^{\text {, }}$. The court defines freedom of religion as a protection against government coercion to express and practice one's own religion without being forced to adopt the ideology or practices of other religion. The court says,

"freedom to enjoy the freedom which my own religion allows without being confined by restrictions imposed by Parliament for the purpose of enforcing the tenets of a faith to which I do not subscribe ${ }^{176}, \ldots .$. it is sufficient in my opinion to say that whatever else freedom of conscience and religion may mean, it must at the very least mean this: government may not coerce individuals to affirm a specific religious belief or to manifest a specific religious practice for a sectarian purpose. ${ }^{77}$

of the legislation's object and its ultimate impact, are clearly linked, if not indivisible. Intended and actual effects have often been looked to for guidance in assessing the legislation's object and thus, its validity. See, $R v$ Big $M$ Drug Mart Ltd.,[1985] 1 SCR 295 at 80.

${ }^{73}$ Ibid at 333.

${ }^{74} \mathrm{Ibid}$ at 295.

${ }^{75}$ Ibid at 95.

${ }^{76} \mathrm{Ibid}$ at 65 .

${ }^{77} \mathrm{Ibid}$ at 123 . 
The court found that the Lord's Day Act breached s.2(a) of the Charter and struck it down due to its coercive nature to compel others to affirm a particular religious practice for sectarian purpose. $^{78}$

Applying the precedent from $R v$ Big M Drug Mart to the case at hand, it can be clearly stated that the criminalization of polygamy is a clear infringement of s.2 (a) of the Charter. It violates the Charter in both ways; by its purpose and its effect, which will be explained shortly. Interestingly, the Supreme Court of BC refused the argument that s.293 is intended to limit religious freedom, by relying on the arguments that prohibition on polygamy was prompted largely by secular concerns with perceived harm associated with this practice to women, children, and society as a whole, as well as to protect the universal institution of monogamy which is embraced by Christianity and has roots in Greco-Roman society. ${ }^{79}$ However, the history of criminalization suggests that it was intended to oppress Mormons, as was indicated earlier.. Despite the fact that there was a colonial bigamy legislation that was able to deal with these rising social concerns, the legislatures felt a necessity to criminalize polygamy specifically since Mormons were starting to immigrate to Canada, and there was an opportunity to avoid the legal issues that Mormons were causing in the US. This is also evident from the Bigamy Working Paper 42 by the Law Reform Commission of Canada cited earlier as well as from the wording of the original Canadian Criminal Code in which the Mormons were explicitly mentioned by name.S.278 of the Canadian Criminal Code 1890, which became s.293 in the current Canadian Criminal Code reads:

Every one is guilty of an indictable offence and liable of polygamy to imprisonment for five years, and to a fine of five hundred dollars, who (a) practises, or, by the rites, ceremonies, forms, rules or customs of any denomination, sect or society, religious or

\footnotetext{
${ }^{78}$ Peter Hogg, Constitutional Law of Canada Student Ed (Toronto: Carswell, 2002) at 888.

${ }^{79}$ Reference re s.293 supra note 12 at 1088.
} 
secular, or by any form of contract, or by mere mutual consent, or by any other method whatsoever, and whether in a manner recognized by law as a binding form of marriage or not, agrees or consents or practise or enter into

(i.) any form of polygamy;

(ii.) any kind of conjugal union with more than one person at the same time;

(iii.) what among the persons commonly called Mormons is known as spiritual or plural marriage; ${ }^{80}$ [Emphasis added ]

It is important to note that this specific reference of Mormons in the Canadian Criminal Code suggests that the legislators targeted them in introducing this provision. This criminal provision was valid for more than fifty years in Canada before it was amended and the word "Mormons" was removed in 1954 and s.278 became s.293. Although, the word "Mormons" was removed, it was not done so to override the actual intent of the legislation, but to broaden the scope of the legislation to cover other ethno-religious groups who practiced polygamy. ${ }^{81}$ According to Professor Durrmond, the 1890 's criminal provision was limited to Mormons and Aboriginals. ${ }^{82}$ However, after removing the word "Mormons," the legislation was able to include other immigrants groups, such as Muslims. Islamic polygamy was also a matter of consideration since the beginning of $19^{\text {th }}$ century, when European Muslims started immigrating to Canada and built the first mosque in Edmonton in $1938 .{ }^{83}$ The Attorney General of British Columbia indicated that Muslim polygamy was already targeted along with Mormons and Aboriginals in 1890's Criminal Code. ${ }^{84}$ Based on these historical facts, it could be stated that section 293 of the Canadian Criminal Code in its purpose violates s.2 (a) of the Charter.

\footnotetext{
${ }^{80}$ The Criminal Code, 1892, 55-56 Vict C 29.

${ }^{81}$ The Constitutional Question Act, Closing Submission of the Attorney General of the British Columbia, [1986] RSBC, c 68,32 at 72-73.

${ }^{82}$ The Constitutional Question Act, Amicus Curiae [1996] RSBC, c 68, vol 180.

${ }^{83}$ Andrea W. Lorenz, “Canada's Pioneer Mosque”, Saudi Aramco Magazine 49 :4 (August 1998)

<http://www.saudiaramcoworld.com/issue/199804/canada.s.pioneer.mosque.htm>.

${ }^{84}$ AGBC supra note $8132-33$ at 72.
} 
Secondly, s. 293 breaches s. 2 (a) in its effects as well. A pioneer Supreme Court case, Syndicate Northcrest v. Amselem, should be discussed for further clarification. In this case, the Supreme Court of Canada defines the "freedom of religion" as follows,

Freedom of religion consists of the freedom...in which an individual demonstrates that he or she sincerely believes or is sincerely undertaking in order to connect with the divine.... irrespective of whether a particular practice or belief is required by official religious dogma... ${ }^{85}$ [Emphasis added]

The sincerity of the belief of the Mormons can be observed in an interview, when the women were asked whether there would be any change in their life if polygamy were decriminalized tomorrow. The participants indicated that it is a central part of their life and religious faith and they will not give it up regardless of whether the state allows it or not. ${ }^{86}$ The reason behind this strong belief in plural marriage is that the main revolution started by the founder of the Mormon Church, Joseph Smith, was to restore the New Testament traditions such as baptism, covenants and ordinances, prophets, rituals, plural marriages and priesthood. ${ }^{87}$ Moreover, it was declared by the Church that polygamy is one of the fundamental tenets of the Mormonism and man's righteousness will be judged based on the size of his family ${ }^{88}$ This is the primary reason why American authority faced such strong resistance from Mormons after banning polygamy. Therefore, there is no doubt that Mormons' beliefs are sincere and protected under the Charter and the criminal provision fails to comply with the definition of the freedom of religion given by the Supreme Court of Canada since it prohibits all forms of polygamous practices.

\section{Freedom of Association:}

\footnotetext{
${ }^{85}$ Syndicat Northcrest v. Amselem [2004] 2 S.C.R. 551 at 56.

${ }^{86}$ Angela Campbell, "Bountiful Voices" (2009) 47Osgoode Hall LJ 183-234.

${ }^{87}$ Bennion supra note 25 at 24.

${ }^{88}$ Ibid.
} 
S.293 of the Canadian Criminal Code denies individual's right to formulate valid marital association with others as well as limits individuals from expressing their relationships. Section 2(d) of the Charter guarantees and "protects the rights of an individual to come together to form a wide array of organizations and relationships, including those with religious political and social" relationships. ${ }^{89}$ While the BC Court of Appeal rejected the claim for freedom of association on the ground that no provincial court extended freedom of association to the inability to marry, ${ }^{90}$ a distinction should be made between inability to marry and preventing people from developing valid religious, marital and social relationships. The criminal provision does not merely prevent individuals from marrying: The Canadian Criminal Code does not say that an individual cannot enter another marital relationship while married, or polygamous marriage would be deemed invalid. Rather, it creates obstacles to legally continuing such a relationship. Therefore, Mormon polygamous marriage should be recognized as valid social and religious association since such a relationship is obligatory, according to the Mormon faith and tradition, as indicated earlier. Consequently, polygamy should be protected under section 2(d) of the Charter.

\section{Freedom of Expression}

The prohibition of polygamy deprives people of their right to freedom of expression by criminalizing any kind of celebration and ceremonial activities of their marriage. The definition of freedom of expression can be found in Irwin Toy Ltd. v. Quebec. The court defined the freedom of expression: "if the activity conveys or attempts to convey a meaning, it has

\footnotetext{
${ }^{89}$ Robert J Sharpe, Katherine E Swinton, Kent Rouch, The charter of Rights and Freedoms $2^{\text {nd }}$ Ed (Toronto: Irwin Law Inc, 2010) at 151

${ }^{90}$ AGBC supra note 81 p11.
} 
expressive content and prima facie (at first glance) falls within the scope of the guarantee". ${ }^{91}$ Peter Hogg commented that most human activities include an expressive element. However, only those activities are protected which are not purely physical and do not convey or attempt to convey any meaning. ${ }^{92}$ Indeed, a marriage ceremony is more than just a registration or social approval of the sexuality of two individuals. A marriage ceremony conveys an important message to society that the people involved in a marriage have changed their social identity from single to married and have made a commitment to each other that they are willing to spend the rest of their life together. A marriage ceremony is not a meaningless celebration. Rather, it carries some important messages. Therefore, it is guaranteed under section 2 (b) of the Charter and s. 293 of the Canadian Criminal Code clearly infringes on this freedom.

\section{Life, Liberty, and Security:}

The most serious infringement of prohibiting polygamy is related to the violation of $\mathrm{s} .7$ of the Charter. A group of rights that are protected under sections 7-14 are also known as legal rights. However, the term "legal rights" have no precise legal meaning except that they protect an individual's rights within the criminal justice system by limiting the state with respect to search, seizure, arrest, detention, trial and punishment. ${ }^{93}$ It should be noted that the rights that are protected under section 8-14 of the Charter are not discussed in this section due to those rights being very specific in terms of their application in a trial. It order to determine whether or not those rights are violated in enforcing the criminalization of polygamy, a case by case analysis should be conducted, and this is beyond the scope of this paper. Nevertheless, according to

\footnotetext{
${ }^{91}$ Irwin Toy Ltd. v Quebec (Attorney General), [1989] 1 SCR 927.

${ }^{92}$ Peter Hogg, Constitutional Law of Canada Student Ed (Toronto: Carswell, 2006) at 986

${ }^{93}$ Ibid at 986.
} 
Professor Hogg, s.7 arguably contains two rights (1) right to life, liberty, and security (2) right not to be deprived of life, liberty, and security except in accordance with the principle of fundamental justice. ${ }^{94}$ He explained that if s.7 is understood as providing two rights then any deprivation of life, liberty and security will be a breach of s.7 even if it complies with principle of fundamental justice. ${ }^{95}$ Therefore, it is more appropriate to read the Article 1 right, which describes the right not to be deprived of life, liberty, and security except in accordance with the principle of fundamental justice. ${ }^{96}$ Nevertheless, in BC Motor Vehicle Act case, Justice Wilson, who wrote the majority decision, adopted two rights' interpretation of s.7 and stated that if state action impaired life, liberty or security of an individual without complying with the principle of fundamental justice, s.7 would be infringed and there cannot be any justification under section $1 .{ }^{97}$ Only in when the life, liberty, or security of a person is infringed in accordance with the principle of fundamental justice, s.1 justification would be required. ${ }^{98}$ However, the threshold for justification of s. 1 in respect to section 7 rights is very high; such infringement cannot be justified except under severe conditions such as war and natural disaster. ${ }^{99}$

Criminalization of polygamy violates s.7 of the Charter in four ways; (1) it deprives individuals from their physical liberty by threatening imprisonment up to five years; (2) it infringes on the security of individuals by causing serious psychological interference with the individual and his or her family; (3) the practical implication of the criminal provision is similar to an absolute liability offense and when it is attached to imprisonment, it automatically breaches

\footnotetext{
${ }^{94}$ Ibid at 957.

${ }^{95} \mathrm{Ibid}$ at 1045.

${ }^{96}$ Ibid.

${ }^{97}$ Re BC Motor Vehicle Act, [1985] 2 SCR 486 at 523.

${ }^{98}$ Ibid.

${ }^{99}$ Suresh v Canada, [2002] 1 SCR 3 at 78.
} 
s.7 rights; and (4) finally, this paper will demonstrate that none of these infringements are in accordance with the principle of fundamental justice.

Section 7 guarantees everyone the right to liberty. Liberty interests are engaged when "any law that imposes a penalty of imprisonment, whether the sentence is mandatory or discretionary, is by virtue of that penalty a deprivation of liberty..." ${ }^{\prime 100}$ Furthermore, liberty in s.7 is not limited to physical liberty, rather, it includes "fundamental personal choices". ${ }^{101}$ Section 293 of the Canadian Criminal Code threats imprisonment up to 5 years to every individual involved in a polygamous relationship. This is a clear violation of the "physical liberty" of an individual. Furthermore, it prevents people from making fundamental personal choices free from "state interference," which is guaranteed by s.7. ${ }^{102}$ The concept of legal liberalism enjoys protection under the Canadian legal justice system. In Godbout v. Longueuil (City,) the Supreme Court of Canada said "the right to liberty enshrined in s.7 of the Charter protects within its ambit the right to an irreducible sphere of personal autonomy wherein individuals may make inherently private choices free from "state interference". ${ }^{103}$ It is assumed in this legal justice system that every individual is a dignified, rational, autonomous, and self-interested being, and this assumption is recognized under s.7. ${ }^{104}$ There is no doubt that an individual's decision regarding marriage is inherently private. In a democratic society, everyone is respected as dignified human beings and can enjoy the autonomy to make a rational and self-interested decision whether or not living in a polygamous or monogamous relationship is right for them. Therefore, someone's decision regarding marriage should be free from state interference and any unjustified interference would constitute an infringement of section 7 of the Charter.

\footnotetext{
${ }^{100}$ Hogg supra note 92 at 1049.

${ }^{101}$ Blencoe v British Columbia (Human Rights Commission), [2000] 2 SCR 307 at 49,54.

102 Ibid at 49,54.

${ }^{103}$ Godbout v. Longueuil (City), [1997] 3 SCR 844, at 66.

${ }^{104} R$ v Clay, [2003] 3 SCR 735 at 31-32.
} 
Secondly, s.293 of the Canadian Criminal Code infringes on "security of the person" interests by causing serious psychological injury to an individual. While the notion of "security of the person" mostly applies within the realm of health and safety, the Supreme Court of Canada indicated that this notion can be extended beyond physical health and safety. In New Brunswick $v G(J)$, the Supreme Court of Canada stated that an application by the state to remove children from parents and place them under state custody, infringes on the "security of the person" of the parents. The court stated that security of the person was affected, because the government action would constitute "a serious interference with the psychological integrity of the parents." 105 In regards to polygamy, it is evident that the accused individuals are subjected to imprisonment which would deprive them from the rest of their family and children; as well criminalization creates a strong social stigma and stereotype against the people involved in polygamy. All these factors undoubtedly affect their psychological integrity and thus deprive them of the right to security that is protected under s.7 of the Charter.

Thirdly, the practical implication of s.293 of the Canadian Criminal Code is similar to the absolute liability offense though it is not explicitly mentioned in the provision. An "absolute liability" offence is one in which no requirement of fault either in terms of negligence or mens rea is required and a defendant could be convicted even if he or she had no intention to break the law and exercised reasonable care to avoid doing so. ${ }^{106}$ When an absolute liability offence is paired with imprisonment, it automatically becomes a violation of s.7. In BC Motor Vehicle Act, the Supreme Court of Canada noted that absolute liability does not per se violate s. 7 of the Charter. ${ }^{107}$ An absolute liability offence violates s. 7 only if and to the extent that it has the

\footnotetext{
${ }^{105}$ New Brunswick v G(J), [1999] 2 SCR 46 at 61; Hogg supra note 92 at 1055.

${ }^{106}$ Hogg supra note 92 at 1071.

${ }^{107}$ Re BC Motor Vehicle Act supra note 97 at 80.
} 
potential to deprive life, liberty or the security of the person. There is no need for that imprisonment be mandatory. ${ }^{108}$ The combination of imprisonment and absolute liability, however, violates s. 7 irrespective of the nature of the offence, and can only be salvaged if the authorities demonstrate, under s. 1, that such a deprivation is a justified limit in a free and democratic society. ${ }^{109}$ It was shown earlier that $\mathrm{s.293}$ is similar to an absolute liability offense in respect to its exercise, it can be concluded that s.293 of the Canadian Criminal Code clearly infringes on s.7 rights of an individual.

\section{Equality Rights:}

Equality lies at the heart of a democratic society. Section 15 of the Charter guarantees everyone the right to equality under the law and protects from unjustified discrimination on some grounds. It reads as;

"every individual is equal before and under the law and has the right to the equal protection and equal benefit of the law without discrimination and, in particular, without discrimination based on race, national or ethnic origin, colour, religion, sex, age or mental or physical disability." Subsection (1) does not preclude any law, program or activity that has as its object the amelioration of conditions of disadvantaged individuals or groups including those that are disadvantaged because of race, national or ethnic origin, colour, religion, sex, age or mental or physical disability". [emphasis added].

The wording guarantees equality before and under the law as well as equal protection and equal benefit of law while articulating specific grounds of discrimination.

Criminalization of polygamy is systemically oppressive to women, and is a mechanism to subjugate and discriminate against religious minority groups from enjoying their rights and freedoms. This is due to the fact that the prohibition makes polygamous family conflicts hidden

\footnotetext{
${ }^{108}$ Ibid at $82-83$.

${ }^{109}$ Ibid.
} 


\section{Page 32 of 64}

from society and sets a barrier from seeking protection from the legal justice system. Moreover, the criminal provision does not include adulterous relationships, ${ }^{110}$ which makes the objective of the criminalization of polygamy vague and unrealistic. It is a systemically oppressive to women because when a married man gets involved in an adulterous relationship with another woman, the law assumes him as well as the woman he is having an affair with to be autonomous, rational and self-interested and imposes no restriction on them. However, when he decides to give her recognition, social status, respect and rights to his property through the bonds of marriage, the legal justice system starts imposing prohibitions. This is how policy makers are systemically oppressing women, creating inequality in the name of equality and harming them in the name of protection.

In Law v Canada, the Supreme Court of Canada held that section 15 violations would require proof of discrimination on an enumerated or analogous ground and substantive discrimination that violated human dignity. ${ }^{111}$ The court also stated that a law can be discriminatory by both its purpose and effect. ${ }^{112}$ Section 293 infringes on s. 15 of the Charter in both ways as it was indicated earlier that the provision targeted religious minority groups such as Mormons, Muslims, and Aboriginal groups. These are the analogous grounds of discrimination mentioned in s.15. Furthermore, criminalization of polygamy prevents people from enjoying equality "before and under the law" and "equal benefits of law". It is apparent from the research done by Angela Campbell that those women who are living in polygamous life cannot enjoy any kind of social benefit and ask for protection under the legal justice system in any situation of domestic violence or matrimonial problems because of their criminalized lifestyle. ${ }^{113}$ They suffer

\footnotetext{
${ }^{110}$ Rex $v$ Tolhurst and Wright, [1937] OR 570.

${ }^{111}$ Law v. Canada (Minister of Employment and Immigration), [1999] 1 S C R 497.

${ }^{112}$ Ibid.

${ }^{113}$ Campbell supra note 86 at $65-78$
} 
strong social stigma and deprivation of rights since they live as law-breakers. ${ }^{114}$ Consequently, they are being doubly victimized.

Additionally, equality was the main reason behind the passing of Bill C-38 which legalized same-sex marriage in Canada. ${ }^{115}$ Some critics argue that criminalizing polygamy is reasonable on equality grounds. For instance, Nicholas Bala argues that polygamy creates inequality between wives and threatens the monogamous family structure whereas same-sex marriage does not. ${ }^{116}$ However, he failed to recognize the arguments made by many critics of same-sex marriage that it threatens the entire traditional institution of marriage and the family system $^{117}$ including monogamy yet it is decriminalized on equality grounds. The question that needs to be answered is, if same-sex marriage can be legalized on the basis of equality and fundamental freedoms, what prevents accepting polygamy on the same ground?

\section{Principle of Fundamental Justice and Justification under s.1 of the Charter:}

\section{Principle of Fundamental Justice:}

In considering whether the criminalization of polygamy can be justified, this section first provides an analysis under the principle of fundamental justice (PFJ) ${ }^{118}$ before conducting an analysis of s.1. As mentioned earlier, when any of the rights guaranteed in s.7 such as "life,

\footnotetext{
${ }^{114}$ Ibid.

${ }^{115}$ Law and Government Division, Parliamentary Information and Research, Legislative History of Bill C-38 (2 February, 2005) (Mary C. Hurley) at 7.

116 Bala supra note 16.

117 George W. Dent, Jr. “How Does Same-sex Marriage Threaten You?” (2006-2007) 59 Rutgers L Rev 233.

118 The concept of Principle of Procedural Fairness does not have a profound and clear meaning in Anglo-Canadian law. This phrase did appear in pre-charter era in Canadian Bill of Rights. However, the meaning of PPF was limited to procedural rights only. It meant 'a fair hearing' and the term fundamental justice was equivalent to the notion of natural justice, which requires an impartial, unbiased, and fair hearing for all trial. However, over time, the Supreme Court of Canada has attempt to remove this ambiguity in BC Motor Vehicle Reference caseby broadening the scope of PPF and including substantive rights. See, Peter Hogg, Constitutional Law of Canada student ed, (Toronto: Carswell, 2006) at 1060-1065.
} 
liberty, and security" is involved, principles of fundamental justice (PFJ) become involved too. It is possible that deprivation of any of those rights is in accordance with principles of fundamental justice, yet not justified under s.1. However, there cannot be any justification under s.1 when such a deprivation is not in accordance with the principle of PFJ. ${ }^{119}$ Furthermore, a point to be noted is that principles of fundamental justice not only include procedural rights, but also substantive rights. There are three principles of fundamental justice:re "arbitrariness," "overbreadth," and "gross disproportionality" involved in regards to s.293 of the Canadian Criminal Code. These three principles will be discussed in detail in upcoming sections.

Section 293 is arbitrary due to the fact that the "principle of arbitrariness" requires a law to be rationally connected to its objective. ${ }^{120}$ This is one of the criterions for the Oaks Test ${ }^{121}$ as well and it will be discussed further in the upcoming sections. However, in Rodriguez v. British Columbia, the Supreme Court of Canada stated that a law is arbitrary where "it bears no relation to, or is inconsistent with, the objective that lies behind [it]". To determine whether this is the case, it is necessary to consider the state's interest and societal concerns that the provision is meant to reflect. ${ }^{122}$ Moreover, in Chaoulli v. Quebec, the Supreme Court of Canada stated:

"in order not to be arbitrary, the limit on life, liberty and security requires not only a theoretical connection between the limit and the legislative goal, but a real connection on the facts. The onus of showing lack of connection in this sense rests with the claimant. The question in every case is whether the measure is arbitrary in the sense of bearing no real relation to the goal and hence being manifestly unfair. The more serious the impingement on the person's liberty and security, the more clear must be the connection. Where the individual's very life may be at stake, the reasonable person would expect a clear connection, in theory and in fact, between the measure that puts life at risk and the legislative goals." [emphasis added]

\footnotetext{
${ }^{119}$ Re BC Motor Vehicle Act supra note 97.

${ }^{120}$ Chaoulli v. Quebec (Attorney General), [2005] 1 S.C.R. 791.

${ }^{121}$ Oaks Test is one of the most important and widely used test in Canadian constitutional law. It was established in a pioneer case $R v$ Oakes [1986] 1 S.C.R. 103. Oaks test is the only test that is used to determine whether or not a violation of any of the rights and freedoms that is guaranteed by the Charter is justified under s. 1 in a free and democratic society.

${ }^{122}$ Rodriguez v. British Columbia (Attorney General), [1993] 3 S.C.R. 519 at 594-95.
} 
The discussion about the historical background of the criminalization of polygamy in Canada shows that the criminalization of polygamy had no rational connection to the objective that the legislation is trying to achieve. While it is argued that the prohibition has a secular purpose that is to protect women and children from harm, this has never been expressly mentioned during the legislative debate on the issue, and there is no factual connection with this objective. This is evident from the fact that in the 1890s, when s.293 was enacted in the Canadian Criminal Code, there were no polygamous practices in Canada. Although Mormons were settled in SouthWestern Alberta, they were not practicing polygamy. Thus, there was no factual evidence of harm present. Rather, it is evident that there were strong moral concerns that motivated the legislatures to impose the prohibition. ${ }^{123}$ Up until now polygamy is criminalized which makes its practice invisible, and as a result there is no empirical evidence ${ }^{124}$ available that clearly suggests that polygamy is harmful for women and children. Therefore, this criminal provision is arbitrary.

The second principle of fundamental justice is the "principle of overbreadth" which states that a law can only limit life, liberty, and security as much as it is necessary to achieve its purpose. ${ }^{125}$ In determining the overbreadth of a legislation, a court must ask whether the means adopted are necessary to achieve the legitimate objectives of the state. ${ }^{126}$ If the means are broader than what is necessary to accomplish that objective, the principles of fundamental justice will be

123 AGBC supra note 81 at 32.

124An important point should be clarified that there is no empirical evidences available in either in Canada or in the US except a few which are conducted recently. Most of the studies that are often cited in the social science literatures and jurisprudences regarding the pros and cons of polygamy are borrowed from the studies conducted in foreign countries in which polygamy is legal or approved practices.

${ }^{125}$ R. v. Heywood, [1994] 3 S.C.R. 761

126 Ibid at 792-794. 
violated because the individual's rights will have been limited for no reason. ${ }^{127}$ In some implications, the effect of overbreadth is that the law is arbitrary or disproportionate.

The wording of s.293 of the Canadian Criminal Code indicates that the legislatures used extensively broader means than what was necessary. First of all, the word "everyone" includes all legal persons regardless of whether they are man and woman. It criminalizes women who are involved in the polygamous relationship and this makes the scope of the legislation unnecessarily broad. While the objective of the law is to protect women from harm and promote equality, in reality, it causes more harm than it prevents. A serious question to be raised is how can a woman be better protected under a law which in and of itself makes her a criminal and threatens her with five years of imprisonment? Secondly, it not only prohibits polygamous marriage, but also criminalizes any kind of conjugal union that may or may not be for the purpose of family or property law, and no evidence is needed to lay the conviction. Also, under s.293.1 (iii), the people involved in performing marital rites, as well as those who are involved in the celebration of the marriage, are also subjected to the indictable offense. In another way of saying, in polygamous marriage, other than the spouses, the clergy who performs the marriage, people who assisted the marriage such as the owner and employees of the convention center where the marriage is held as well as the guests who are invited are subjected to criminal conviction regardless of whether they intended to assist polygamous marriage or had taken enough precautions to avoid it. Professor Durrmond has pointed out that the legislation's wording such as "everyone," "any form of polygamy," and "any kind of conjugal union whether or not it is by law recognized as a binding form of marriage," are so broad and vague that it becomes virtually

${ }^{127}$ Ibid. 
impossible to articulate what the criminal conception of polygamy amounts to and what the core mischief is that it underlies. ${ }^{128}$

The third principle of procedural fairness is the "principle of gross disproportionality". The principle of gross disproportionality requires the court to determine whether or not the legislation has a grossly disproportionate impact on the accused. According to Canada (Attorney General) v. Bedford, a grossly disproportionate analysis begins with questioning whether or not the state has a legitimate interest to limit rights, and if so, whether or not the infringement of the Charter is proportionate to the state interest perused. ${ }^{129}$ This test reflects the s. 1 proportionality test, which is also known as the Oaks Test. This will be discussed further in upcoming sections. However, it should be noted that in determining the breach of s.7, there is no need to conduct an analysis for justification under s.1 if a legislation fails to comply with the principles of fundamental justice. As it is shown that the s.293 fails to comply with the principles of procedural fairness, justification under s. 1 is analyzed to determine the proportionality in regards to the infringement of the other sections of the Charter.

\section{Section 1 Analysis:}

Justification under s. 1 requires a four steps proportionality test according to $R v$ Oaks. ${ }^{130}$ The first two criterions are that there must be a sufficiently important objective and it has to be rationally connected. ${ }^{131}$ Although the objective of the Canadian Criminal Code can be found in a parliamentary debate, in which the purpose of the prohibition was mentioned to create equality

\footnotetext{
${ }^{128}$ Drummond supra note 53 at 95.

${ }^{129}$ Canada (Attorney General) v Bedford, 2012 ONCA 186 at 412.

${ }^{130} R$ v Oakes, [1986] 1 SCR 103.

${ }^{131}$ Hogg supra note 92 at 779.
} 


\section{Page 38 of 64}

between spouses, ${ }^{132}$ its actual purpose is to subjugate religious minority groups, as is evident from previous discussions. Nevertheless, it should be restated that there is no empirical evidence available in Canada at this moment suggesting that polygamy is a harmful practice, since such practice is illegal and hidden. Therefore, to find information about the advantages and disadvantages of polygamous relationships, researchers have no choice but to rely on data from other countries, where polygamy is legalized.

In a policy report, Angela Campbell suggests that the global response to polygamy is diverse, and that it is impossible to draw a single unqualified conclusion whether it is harmful for women. ${ }^{133}$ After reviewing extensive amounts of literature on this topic, she states that "it is impossible to reduce the literature on this topic to a general, blanket statement in regard to the social aspects of polygamous life for women: polygamy is neither entirely "good" nor is it entirely "bad" for women". ${ }^{134}$ On to the hand, in justifying the criminalization, the Supreme Court of $\mathrm{BC}$ argued that there is evidence in social science literature from various countries that indicates the harmful impact of polygamy. The court states that there are significant amounts of domestic violence, sexual abuse, infant mortality, fractious co-wife relationships, and higher rates of repressive disorder associated with polygamous marital relationships. ${ }^{135}$ However, the point where the court erred is that most of the evidences come from the Middle-Eastern, SouthAsian and African countries whose socio, economic, and political culture is completely different from that of Canada. There is very little or no evidence available from the countries which are comparable to Canada in terms of socio-economic and political aspects since polygamy is also

\footnotetext{
${ }^{132}$ Debates of the House of Commons, 6th Parl, 4th Sess, (10 April 1890) (Sir John Thompson), House of Commons, 40th Parl, 3rd Sess, No. 42 (March 26, 2011) (Hedy Fry).

${ }^{133}$ Campbell supra note 8 at 2.

134 Ibid at 3.

${ }^{135}$ Reference re: Section 293 supra note 12 at 779-790.
} 
banned by them. Therefore, there is no factual connection between the law and its objective. Moreover, the fact that criminalization creates inequality rather than equality, is sufficient to demonstrate the lack of rational connection.

The two other criteria are that "the measures used" should impair as little as possible rights and freedoms (no more than necessary) and the law must not have a disproportionately severe impact on the person whom it applies to. ${ }^{136}$ As it was indicated, the impact is not little, since it completely denies freedom of religion and forces people to adopt the model of JudeoChristian monogamous marriage for sectarian purposes. It denies individual's autonomy and "fundamental personal choice" as well as depriving them from forming valid marital relationships. This is a serious infringement on an individual's life, liberty, and security because in this justice system, preservation of autonomy is considered somehow much more important than preservation of life. ${ }^{137}$ A logical question should be raised, that if preservation of life cannot be a justifiable reason to limit someone's autonomy, how can preservation from hypothetical harm without factual relationship be a reasonable justification to limit someone's Charterprotected rights? Therefore, the infringements have disproportionately severe impacts on the people involved and the law impairs their rights more than necessary to achieve its objectives. Consequently, these violations are not justified under s.1 of the Charter in a free and democratic society.

\footnotetext{
${ }^{136}$ Hogg supra note 92 at 961.

${ }^{137}$ See, Malette v Shulman, [1990] 72 OR (2d) 417 in which the SCC awarded Mrs. Mallette who is a Jehovah Witness damages for the blood transfusion that was performed by Dr. Shulman without her consent.
} 


\section{Chapter 3}

\section{Sociological Approach to Polygamy:}

"We have prostitutes for our pleasure, concubines for our health, and wives to bear us lawful offspring." 138

(Demosthenes, Ancient Greek statesman and orator of ancient Athens)

One of the justifications often provided by defenders of the criminalization of polygamy is that polygamy has a negative impact on society as a whole, since it is associated with gender inequality and discrimination, and weakens family ties, while monogamy promotes equality between spouses and strengthen the family ties. This chapter elaborates on this issue, demonstrates some of the weaknesses of monogamy, and explains how prohibiting polygamy actually creates more inequality and discrimination in the society.

\section{Polygamy and Equality:}

Polygamy has always been criticized on the grounds of inequality and discrimination. Critics often argue that polygamy promotes gender inequality between man and women and discriminates women disproportionately. Although this topic was briefly touched in the previous sections, this section tries to provide a deeper elaboration. While it seems that criminalization of polygamy secures the interests of women by promoting equality and preventing discrimination, a

\footnotetext{
${ }^{138}$ Lee S. Dimin, Corporatocracy: A Revolution in Progress (Bloomington: iUniverse, 2011) at 283.
} 
critical analysis of the prohibition within a large context reveals that it, in fact, promotes more inequality and discrimination.

Colleen Sheppard developed a theoretical framework, which she calls "inclusive equality" to examine conflicting equality and discrimination claims in a broad social context. She suggests that "to secure greater equality, it is critical to examine both the inequitable substantive outcomes in various social contexts as well as unfairness and exclusions in the structures, processes, relationship, and norms that constitute the institutional contexts of our daily life". She argues that looking at conflicting equality and discrimination claims provides important insights into the dynamic reproduction of inequality and exclusion that has been established over time, and reveals how some institutional relationships promote equality while others do not. ${ }^{139}$ The idea that "inclusive equality" stresses is that in order to determine true equality, the powers and mechanisms individuals are given to contest and resist exclusions and marginalization must be examined. ${ }^{140}$ Inclusive equality also requires an assessment of how social, economic, political and cultural forces constrain individuals and groups from claiming their equality rights. ${ }^{141}$ This theoretical framework can be a useful mechanism to examine the criminalization of polygamy in a broad social context.

The quote from Demosthenes at the beginning of this section reflects the ancient Greek understanding of marriage (mostly monogamous) in which women were viewed as an object of pleasure, healthcare, and a vessel for the production of children. Unfortunately, the modern day prohibition of polygamy in its "substantive outcomes" promotes a similar approach and understanding of marriage and women. This is due to the fact that the criminalization of

\footnotetext{
${ }^{139}$ Colleen Sheppard, Inclusive Equality: The Relational Dimensions of Systematic Discrimination in Canada (Quebec: McGill-Queen's University Press, 2010) at 4.

${ }^{140}$ Ibid.

${ }^{141}$ Ibid.
} 
polygamy does not include any kind of adulterous relationships which was clarified in Rex v Tolhurst and Wright. In this case, the Ontario Court of Appeal was asked whether the wording "any kind of conjugal union" includes adulterous relationship. The court clarified that this crucial wording refers to polygamous and spiritual marriages and the parliament had no intention to include adulterous relationship. ${ }^{142}$ This lead many critics of the prohibition on polygamy, such as Dalton, to raise this question: If adultery is not a crime in our society, why should polygamy or bigamy be ${ }^{143}$ One of the possible answers this question is that criminalization of polygamy is a mechanism of subjugating women; a way to use one's wife as a vessel of reproduction and other women outside of marriage as objects of pleasure.

While discussing polygamy, it is extremely important to take adultery into consideration, since adultery is a very common problem in the Western monogamous world, and has practically similar implications as polygamy. Adultery is defined as "the voluntary sexual intercourse of a married person with a person other than the offender's husband or wife". ${ }^{144}$ In fact, some argue that even divorce is a way of serial polygamy, and if polygamy should be banned, then divorce should not be allowed either. ${ }^{145}$ This argument actually reflects the biological definition of monogamy and polygamy. Biologists and psychologists state that human beings are not a biologically monogamous species since a biological definition of monogamy requires humans to stick with their first sexual partner without any dalliance or departure until they die. ${ }^{146}$

Criminalizing polygamy, but not adulterous relationships, promotes inequality and impacts marital relationship detrimentally in two ways: by giving man the opportunity to enjoy

\footnotetext{
${ }^{142}$ Rex $v$ Tolhurst and Wright, [1937] OR 570 at ROWELL CJO.

${ }^{143}$ CRM Dlamin, "Should we legalise or abolish polygamy?” (1989), 22 Comp \& Int'l LJ S Afr 330 at 341.

${ }^{144}$ Black's Law Dictionary, $2^{\text {nd }}$ ed, sub verbo “adultary" <http://thelawdictionary.org/adultery/\#ixzz2bo5oJGU4>.

${ }^{145}$ Dlamin supra note 143 at 339.

${ }^{146}$ Barash, D P, \& Lipton, J E, The Myth of Monogamy: Fidelity and Infidelity in Animals and People, (New York: Holt Paper Back, 2002).
} 
women for pleasure without having to marry, give socio-legal status, and appropriate rights in his property as well as by depriving wives from love, affection and support while using as the wife as a vessel for reproduction. Furthermore, adulterous relationships have a negative impact on marital relationships. It creates jealousy, mistrust and conflict between married couples that lead to the destruction of their marriage, and hinders the wellbeing of both the legal children, as well as the children who are born of the adulterous relationship.

Divorce has been one of the most common social problems in the Western monogamous world, such as Canada and the US, for a long time. Although the number of divorces was not that high under the old divorce regime, infidelity was still one of the grounds for seeking divorce. However, after the introduction of "no fault divorce" in Divorce Act 1968, divorce process became much easier and the number of divorce started drastically rising. According to Statistics Canada, there were 70,226 divorces occurred in 2008 and every four out of ten $1^{\text {st }}$ marriages ended in divorce in 2010. ${ }^{147}$ The situation in the US is not any better than Canada. According to the latest 2010 censes, about 10 percent of the entire adult population (approximately 27 million) of the US was divorced. ${ }^{148}$ Several academic researches indicate that one of the primary reasons behind divorce is infidelity. For example, In a longitudinal study, Amato and Rogers indicate that one of the strongest and consistent predictor of divorce is infidelity. ${ }^{149}$ Similarly, Laumann, Gagnon, and Michael found in a cross-sectional study that people were more likely to report adultery in marriages that ended in divorce than in marriages that were intact at the time of the

147 "4 in 10 1st Marriages end in Divorce: Report", CBC News (4 October 2010) http://www.cbc.ca/news/canada/story/2010/10/04/vanier-study004.html

${ }^{148}$ Anne Milan, Marital Status: Overview 2011, Online: Statistics Canada <http://www.statcan.gc.ca/pub/91-209x/2013001/article/11788-eng.htm>.

${ }^{149}$ Amato, P R, \& Rogers, S J, “A Longitudinal Study of Marital Problems and Subsequent Divorce”, (1997) 59 J. Marriage Fam 612. 
interview. ${ }^{150}$ Moreover, South and Lloyd (1995) reported that at least one former spouse had engaged in adultery in one out of every three divorces, before the marriage had even ended. ${ }^{151}$ Amato and Previti used national panel data collected between 1980 and 1997 to classify 208 people's open-ended responses to a question on why their marriages ended in divorce. They found that although people have specific reasons for divorce that varied with gender, social class, and life course variables, infidelity was the most commonly reported cause followed by incompatibility, drinking or drug use, and growing apart. ${ }^{152}$

Infidelity promotes discrimination not only to the children who are born from adultery, but also to the legal children born from monogamy, and hinders their wellbeing. About 3 percent of children are born from infidelity ${ }^{153}$ and one out of every six children in Canada is victim of child identity fraud. ${ }^{154}$ Children that are born in an adulterous relationship are more likely to be raised by a single mother or stepfather, thus they are often deprived of proper parental care. Research suggests that $24 \%$ of American children under the age of 18 live in single-mother families. ${ }^{155}$ Canadian Children Rights Council suggests that fatherlessness is one of the biggest problems in Canada, and father-deprivation is a more reliable predictor of criminal activity than race, environment or poverty. They suggest that 72 percent of child murderers, 60 percent of rapists and 80 percent of adolescents who are in psychiatrist hospitals are victims of father-

\footnotetext{
${ }^{150}$ Laumann, E O, Gagnon, J H, Michael, R T, \& Michaels, S The social organization of sexuality: Sexual practices in the United States (Chicago: University of Chicago Press, 1994).

${ }^{151}$ South, S. J., \& Lloyd, K. M. (1995) "Spousal alternatives and marital dissolution” 60 Am Sociol Rev 21 at $21-35$.

${ }^{152}$ Amato and Previti "People's Reasons for Divorcing: Gender, Social Class, the Life Course, and Adjustment" (2003) 24 J. Fam. Issues 602 at 602.

${ }^{153}$ Infidelity Statistics, Online: Statistics Brain <http://www.statisticbrain.com/infidelity-statistics/>.

${ }^{154}$ Cheating on your spouse and the effect on the resulting children

Online: Canadian Children Rights Council, http://www.canadiancrc.com/Infidelity.aspx

${ }^{155}$ Mark Mather, "US Children in Single-Mother Families" Online: The Population Reference Bureau, <http://www.prb.org/pdf10/single-motherfamilies.pdf>.
} 
deprivation. ${ }^{156}$ Similarly, a study conducted by Rebecca O'Neill reveals that children who grew up fatherless are eight times more likely to go to prison; five times more likely to commit suicide; twenty times more likely to have behavioral problems; ten times more likely to abuse chemical substances and nine times more likely to drop out of high school. ${ }^{157}$ American researches suggest that children face significant challenges in making the transition into adulthood and that the children in single-parent families face the most significant barriers to success in school and in the work force ${ }^{158}$ Furthermore, women who raise children alone face significant challenges and difficulties in their daily life. One of the biggest risks that a single mother faces is poverty. Mark Mather reports that " 7 in 10 children living with a single mother are poor or low income, compared to less than a third of children living in other types of families". 159

\section{Chapter 4}

\section{Benefits of Legalizing Polygamy:}

There are a number of benefits that can be achieved if polygamy is made legal in Canada. Although this chapter discusses only six of these benefits, there might be more benefits than those analyzed. The six benefits are (1) establishment of rule of law, constitutionalism, and respect for minorities' cultures; (2) efficient regulation of polygamy; (3) safer environments for

\footnotetext{
${ }^{156}$ Fatherlessness is one of the Grates Problems in Canada, Online: Canadian Children Rights Council, $\langle$ http://www.canadiancrc.com/Fatherlessness/Fatherlessness_in_Canada.aspx > .

${ }^{157}$ Ibid.

${ }^{158}$ Mather supra note 155.

${ }^{159}$ Ibid.
} 
women who are already living in polygamous marriages illegally; (4) better family management; (5) improved children's wellbeing; (6) and production of knowledge. The previous sections of this paper discuss the fact that research suggests that polygamy is neither entirely harmful nor is it entirely beneficial; there is evidence of both, which makes it difficult to make a blanket statement. However, the legalization of polygamy in Canada will bring more benefit than harm since most the harms that are associated with polygamy are found in countries whose socio-legal, economic and political culture is completely different. The most commonly referenced harms of polygamy are poverty, domestic violence, child abuse, negative impact on children's wellbeing and education, poor health conditions, and an increased rate of sexually transmitted disorders. ${ }^{160}$ Many of these harms are not major concerns in a developed welfare state, such as in Canada. The countries where domestic violence problems are most prevalent, such as Ghana, Mali, Palestine, Niger, Afghanistan and Nigeria ${ }^{161}$, do not have a very strong legal protection for women in their legal justice systems, and the culture tends to favor the man in case of family dispute. This is opposed to Canada, where the offenses of domestic violence, such as assault, sexual harassment, and child abuse and abandonment, are crimes and subject to the Canadian Criminal Code. ${ }^{162}$ The legal justice system takes a very strict and reactive approach to prevent women from such violence.

In regards to children's wellbeing, Canada is a welfare state with better financial positions for people and social assistance programs that ensure children's wellbeing. Children's

\footnotetext{
${ }^{160}$ Committee on the Judiciary United States Senate, Crimes Associated with Polygamy: the Need for Coordinated Senate and Federal Response (July 24, 2008) (Chair: Patrick J Leahy).

${ }^{161}$ Robert Lalasz, Domestic Violence in Developing Countries: An Intergenerational Crisis Online: Population Reference Bureau < http://www.prb.org/Publications/Articles/2004/DomesticViolenceinDevelopingCountriesAnIntergenerationalCrisis.a $\mathrm{spx}>$

${ }^{162}$ Family Violence Laws, Online: Department of Justice < http://www.justice.gc.ca/eng/cj-jp/fv-vf/laws-lois.html>.
} 
wellbeing is hindered in the countries that are most commonly analyzed when the harms of polygamy is referenced, because they do not have adequate resources to ensure the needs of the children, such as proper family care, nutrition, and education. On the other hand, Canada ensures that every child has access to universal healthcare, child benefit and support programs, mandatory education requirements, and other social services. Therefore, the detrimental factors that are most commonly associated with polygamy are not really major concerns in Canada, as they are in those countries. Consequently, it is more likely that the benefits of legalizing polygamy will outweigh the risks that are associated with this practice. Nevertheless, there are few more advantages that can be achieved by legalizing polygamy discussed below.

\section{Establishment of Rule of Law, Constitutionalism and Respect for Minority:}

The Canadian Constitution is the supreme law of Canada, and includes the Canadian Charter of Rights and Freedoms. According to the Constitution of Canada, constitutional monarchy is one of the fundamental aspects of Canadian constitutionalism. S. 52 of the Constitution says, "the Constitution of Canada is the supreme law of Canada, and any law that is inconsistent with the provisions of the Constitution is, to the extent of the inconsistency, of no force or effect". As argued earlier, the criminalization of polygamy seriously infringes on Charter protected rights and freedoms of an individual, which is unjustifiable in a free and democratic society. Therefore, in order to protect and maintain the fundamental aspect of constitutionalism and the rule of law, polygamy should be legalized. Moreover, the criminalization of polygamy seriously undermines the constitutional notion of "respect for minority," which is considered to be one of the 
fundamental principles of Canadian constitution. ${ }^{163}$ Legalizing polygamy will preserve and uphold these central tenets of the Constitution of Canada.

It goes without saying that religion and culture play an extremely important role in the practices of polygamy. It has been addressed before that polygamy is one of the fundamental tenets of Mormonism and is also approved by Islam. Though polygamy is not accepted among the Jews and the mainstream Christians, such as Protestant and Catholics, biblical narratives or prophets and patriarchs gives strong supportive evidence of polygamy that was practiced in earlier in the tradition.

Polygamy has always been practiced among the members of the First Nation communities. Their polygamous practices were so profound and deeply rooted in their culture that the criminalization of polygamy was not intended to control the aboriginal polygamous marriages for a long time. ${ }^{164}$

\section{Efficient regulation of polygamy and safety for women:}

An important point to be noted is that although polygamy has been criminalized for more than a hundred years in the United States and Canada, it has still been practiced by a large number of people. According to The New York Times, there are between 50,000 and 100,000 people living in polygamy only in the United States. ${ }^{165}$ There are also approximately 3000

\footnotetext{
${ }^{163}$ Justice Ian Binnie, "Justice Charles Gonthier and the Unwritten Principles of the Constitution" (A Symposium in Honor of Charles D Gonthier, delivered at the McGill University, May 20-21, 2011 <http://cisdl.org/gonthier/public/pdfs/papers/Confrence_Charles_D_Gonthier_-_Ian_Binnie.pdf >.

${ }^{164}$ Kaufman supra note 5 at 2.

${ }^{165}$ Felicia R. Lee, "Big Love: Real Polygamist Look at HBO Polygamist and Find Sex " The New York Times, (March 28, 2006) <http://www.nytimes.com/2006/03/28/arts/television/28poly.html?pagewanted=all\&_r=0>.
} 
people living in polygamous families in Bountiful, British Columbia. ${ }^{166}$ Nevertheless, the Bountiful community of British Columbia and many other religious and cultural groups have been openly practicing polygamy without seeking any legal recognition. In these instances, the Canadian Criminal Code is not applied by the law enforcement agencies due to the fear that the criminal prohibition might be challenged and struck down in the court on grounds of Charter violation. This approach actually creates a legal vacuum in which an inapplicable law fails to address the social problems, while creating unnecessary legal obstacles. Legalization of polygamy would address this legal vacuum and make the other laws applicable and be able to deal with the social problems.

Furthermore, many women who live in polygamy never intend to leave this lifestyle. ${ }^{167} \mathrm{~A}$ majority of them are living without any legal status. As a result, they are deprived of any protection under the legal justice system. Furthermore, they are unable to come forward to express their concerns since they are already considered criminal under the criminal provision. In cases of domestic violence or other forms of marital injustice, they have to remain silent . If polygamy was legalized, it would give them the opportunity to come forward with their disputes, make their disputes visible, and seek protection under the legal justice system. Duncan says that it, "would elevate some of the abuses prevalent in polygynous communities because it will lead to greater regulation" and bring them into the open for all citizens to examine polygamous marriages. ${ }^{168} \mathrm{He}$ thinks that the legalization of polygamy will encourage patriarchs to register the marriage which will give the women more accessibility to the outside world. ${ }^{169}$ Moreover, the government will be able to develop proper regulations addressing every single issue that men and

\footnotetext{
${ }^{166}$ Campbell supra note 86.

${ }^{167}$ Ibid.

${ }^{168}$ Emily J. Duncan, "the positive effects of legalizing polygamy: Love is a many splendid thing" 15 Duke J. Gender L. \& Pol'y (2008) at 316.

${ }^{169}$ Ibid.
} 


\section{Page 50 of 64}

women face in polygamous marriages. This will make women better protected and safer under the law.

\section{Better family management:}

While polygamy has often been criticized for promoting jealousy and rivalry between the wives, some studies (which ones? Reference?) in FLDS communities and from foreign countries where polygamy is allowed suggest that there is very little jealousy and rivalry found in polygamous relationships. National Geographic magazine reports that there is very little jealousy problems found among the women who live in FLDS communities in the United States, due to the allocation of labor among the wives and the responsibilities for their own children. ${ }^{170}$ Conley and Moors and their colleagues conducted four studies about this topic and claimed that, in fact, "a major perceived benefit of monogamy is the avoidance of jealousy;" participants frequently mentioned that "no jealousy issues," "prevents jealousy," and "no jealousy/competition" were the advantages of monogamy. ${ }^{171}$ Although it is believed that monogamy inhibits jealousy, studies show that monogamy does not entirely prevent jealousy and it may actually be less severe, more manageable, or even non-existent among individuals in non-monogamous lifestyles. ${ }^{172}$ Gregory White and Paul Mullen report that, "most available ethnographic evidences suggest that multiple wives in polygamous societies do not become jealous unless the husband shows favoritism to

\footnotetext{
${ }^{170}$ Philip L Kilbride and Douglas R Page, Plural Marriage for Our Time: a Reinvented option $2 d$ ed., (California; Preager, 2012) at 53.

${ }^{171}$ Terri D. Conley, Ali Ziegler, Amy C. Moors, Jes L. Matsick, and Brandon Valentine, “A Critical Examination of Popular Assumptions About the Benefits and Outcomes of Monogamous Relationships" 17 Pers Soc Psychol Rev 124 at 130.
} 
one wife or her children that is not in accordance with cultural prescriptions about how attention and reward should be distributed among wives."173

Polygamy decreases the burden of domestic work for women. Ware conducted a survey among the women in Nigeria and learned that most wives who are living in polygamy view it as a means of companionship and partnership, in which they can share their household work and responsibilities. ${ }^{174}$ Interestingly, in a survey with more than 6000 Yoruba (the second largest city of Nigeria) females, who are between the age of 15 and 59, Ware found that more than $60 \%$ of the women in the survey reported that they will be pleased if their husband takes another wife, given the explanation that they will assist them in the management of household work and responsibilities. $^{175}$

Additionally, the legalization of polygamy empowers women in the domestic decisionmaking process. Although polygamy has been criticized, based on the idea that it promotes oppression of women, and male dominance in households, it has been found that women in polygamous families enjoy considerable autonomy and dominance in their households. Angela Campbell discovered in her interview with the women of Bountiful that women do not have to share their incomes with their husband, and they unite and exercise a stronger voice in the family's decision making process. ${ }^{176}$ The unity between wives helps them protect their interests in the household.

\section{Social and Economic Benefits of Polygamy:}

\footnotetext{
172 Ibid.

${ }^{173}$ Gregory White and Paul Mullen, Jealousy: Theory, Research and Clinical Strategies, (New York: Guilford Press, $1989)$ at 146.

${ }^{174}$ Kilbride and Page supra note 170 at 55.

175 Ibid.

${ }^{176}$ Campbell supra note 86.
} 
One of the most important and influential factors behind polygamy is financial. In almost every society, women are more likely to get involved in polygamous marriage in order to secure their economic situations. Psychological research indicates that one of the most common factors that women consider for marriage is financial security. ${ }^{177}$ Born B Ingoldsby suggests that families that are wealthiest in a polygynous society are more likely to be polygynous. Whenever the wives and children are able to contribute in the production of wealth, polygyny is likelier to be practiced. ${ }^{178}$ Similarly, there is a widespread practices of polygamy in Africa in a form called "sugar daddy". A "sugar daddy" is typically an old rich man who takes younger women for sex and romance with the exchange of financial resources. ${ }^{179}$ Furthermore, in an investigation of the polygamous marriages among the educated people in Saudi Arabia, Maha Yamani found that although Islam condones polygamy, increase of oil wealth makes it possible for man to afford and practice polygamy while creating an incentive for women to marry a wealthy man who has married previously. ${ }^{180}$

There are many social and economic benefits of polygamy for men and women. Lawyer and Journalist, Elizabeth Joseph, who lived in a polygamous lifestyle with her husband, Alex, in Utah in the mid-1990s, is one of the most outspoken advocates of the social and economic benefits of polygamy. She indicated that polygamy is a good choice for women who would like to pursue a professional career as her sister wives cared for her son while she worked, preventing her from spending money on daycare. ${ }^{181}$ She also indicates that since her sister wives had

\footnotetext{
${ }^{177}$ Dr Wayne Weiten Dr Doug McCann, Psychology: Themes and Variations (Scarborough: Nelson College Indigenous, 2009) at chapter 16.

${ }^{178}$ Bron B. Ingoldsby, Families in Global Canada and Multicultural Perspective (Thousand Oaks, CA: Sage Publications, 2006) at 101-102.

${ }^{179}$ Kilbride and Page supra note 170 at 47.

${ }^{180}$ Maha A.Z Yamani, Polygamy and Law in Contemporary Saudi Arabia (Berkshre: Ithaca press, 2008) at 215.

${ }^{181}$ Kilbride and Page supra note 169 at 46.
} 
different career interests, she was able to pursue her career full-time. ${ }^{182}$ Yamani notes that there are many women who prefer marrying a man who is already married to avoid having more children and responsibilities. ${ }^{183}$ Moller and Welch conducted a research with the Zulu men and indicated that the Zulu men, who favored polygamy, reported higher job satisfaction, feeling far less lonely, more voluntary retirement, better health, higher degrees of social adjustment, including better adjustment to aging and retirement, than their monogamous fellows. ${ }^{184}$

As mentioned earlier, since the criminalization of polygamy does not include adulterous relationships, infidelity is a very common problem in monogamous relationships. There are a large number of women who are already living in polygamy without any legal rights and status. As such, women can potentially be degraded and deprived of their property rights and sociolegal status. It can force them to live as single mothers with social and financial hardships. If polygamy is legalized, women's right over the property of their husbands can be ensured. Specially, upon divorce, women do not have to leave with empty hands, since their marriages will be given recognition and they will be able to come forward to claim their rights. Moreover, the legalization of polygamy will also open the door for many spousal benefits forms of social support for women and ensure their equality with the other first wives of their husband, who receive those benefits legally.

One of the most important roles that legalization of polygamy can play is removing social stigmas and stereotypes about women and children who are living in polygamy. As indicated by Angela Campbell in her qualitative research, women in Bountiful face a strong social stigma and

\footnotetext{
${ }^{182}$ Ibid.

${ }^{183}$ Yamani supra note 180 at 231.

${ }^{184}$ Valerie Moller and Gray John Welch, "Polygamy, Economic Security and Well-being of Retired Zulu Migrant Workers" (1990) 5 Journal of Cross-Cultural Gerontology 205.
} 
stereotyping, which is created by criminalization. ${ }^{185}$ Legalization of polygamy can play an extremely important role in protecting those vulnerable women and children and integrate them in the mainstream society. Women in Bountiful indicated that they do not go outside of their community to work or pursue an education because they do not want to be seen as a criminals. ${ }^{186}$ Legalizing polygamy is the only way to solve those aforementioned problems.

\section{Children's Wellbeing:}

While it is often argued and assumed that polygamy has a detrimental impact on the wellbeing of children, research shows findings contrary to this assumption. Elizabeth Sheff conducted a longitudinal study with polyamorous ${ }^{187}$ families and reported a number of benefits that the children of these families enjoy. She indicates that due to the flexibility of having multiple parental figures involved in their lives, the children had more individualized time with adults and could spend less time in day care. ${ }^{188}$ Similarly, the children that come from these families foster a wider variety of hobbies and skills because of the greater diversity of interests available from adult figures helped them to do so. ${ }^{189}$ Polyamorous parents also felt that there is honesty between children and parents since the children were being raised in a sex-positive environment and that allowed children to see their parents as real people. ${ }^{190}$ Angela Campbell also reported that sister wives in Bountiful often cooperate with each other in taking care of their children, thus, their children are never left without proper parental care. ${ }^{191}$

\footnotetext{
${ }^{185}$ Campbell supra note 86.

${ }^{186}$ Ibid.

${ }^{187}$ The state or practice of having more than one open romantic relationship at a time see, Merriam-Webstar Dictionary, sub verbo "polyamory" <http://www.merriam-webster.com/dictionary/polyamory>.

${ }^{188}$ Elizabeth Sheff, "Strategies in Polyamorous Parenting", in M Barker \& D. Langridge (Eds.), Understanding nonmonogamies (New York: Routledge, 2010) at 169-181.

${ }^{189}$ Ibid.

${ }^{190}$ Ibid.

${ }^{191}$ Campbell supra note 86.
} 
Moreover, legalization of polygamy can be a very effective way to avoid the harms that are associated to with the practices of monogamy. As mentioned earlier, infidelity is a very common problem in monogamous marriages and one of the main reasons behind divorce. Legalization of polygamy will not only help in reducing the rate of divorce but will also help to avoid the negative impacts of divorce on children. Studies suggest that children whose parents' relationship dissolved as a result of infidelity, tend to have insecure attachment styles ${ }^{192}$ and children whose parents commit infidelity are more likely to grow up to cheat on partners themselves. ${ }^{193}$

The preceding sections of this paper discussed how the prohibition on polygamy is associated with a higher number of single mothers, and that those single mothers face a considerable amount of hardship in raising their children without proper support . Poverty, poor health, and poor accommodation are very common challenges that single mothers face in raising their children, which significantly hinders their children's wellbeing. Moreover, fatherlessness is another serious social concern that is associated to detrimental impact on the child's life and wellbeing. If polygamy is legalized, it will be more likely that children will be able to get better parental care and grow up with proper social and financial support.

\section{Production of knowledge:}

As referenced earlier, one of the pragmatic barriers in conducting research about polygamy is that there is no empirical evidences available in Canada with regards to polygamy. The legalization of polygamy can be an excellent way to generate knowledge for further research

\footnotetext{
${ }^{192}$ Platt, R A L, Nalbone, D P, Casanova, G M, \& Wetchler, J L "Parental conflict and infidelity as predictors of adult children's attachment style and infidelity” (2008) 36 Am J Fam Ther 149.

${ }^{193}$ Conley and Moors supra note 171.
} 
and analysis that can later help develop more effective and balanced public policy. Legalization will also allow judges to make more informed decisions regarding marital disputes in polygamous and bigamous individuals. An American judge called Richard A. Ponser expressed his concern that judges and lawyers have limited knowledge on sexual matters. He writes in his book Sex and Reason,

The narrowness of legal training is an old story but a true one... A [Lawyer specializing] in the Fourteenth Amendment is expected to know a lot of judicial option and legal doctrinal niceties but is neither expected nor likely to know much about the history, nature and practices of sexual regulation. It is not helpful, in this regard that sex remains a taboo subject in our society ... The less that lawyer know about a subject, the less that judges will know; and the less that judges know, the more likely they are to vote their prejudices"

This is an important area that should be made open to more research and analysis and this can be done through legalization of polygamy.

\section{Conclusion}

This paper demonstrates that the issue of the criminalization of polygamy is something that every Canadian needs to be concerned with, because it infringes on rights that are inherently protected by the Charter. In chapter one of this paper, the history of this criminalization was discussed. The history of polygamy and its criminalization in the United States is also discussed, because it is related with its Canadian counterpart. Although this paper focused on the history of Mormonism more than other polygamy-practicing religions and cultures such as Islam, this paper calls for lifting the ban on all Canadians. At this point it should be stated that the

criminalization of polygamy violates the religious freedoms and the freedom of expression of Mormon people, and that it upholds the religious ideals supported by Judeo-Christian and Hellenistic traditions. 
There are various stigmas and stereotypes associated with women and men who engage in polygamous marriage. However, simply using these stigmas and stereotypes to criminalize their marriages without basing the ban on any real study on the polygamous populations in Canada (or any other Western society, for that matter), is illogical and arbitrary. Proponents of the ban argue using studies that are conducted in societies that are vastly different from Canada. They correlate all sorts of negative measurements with polygamous marriage, such as high infant mortality, spread of diseases, lower life expectancy, and higher rates of domestic abuse, without taking into fact that these societies are vastly different from Canada's. They have vastly different laws, healthcare programs, and approaches to solving legal disputes.

There are several reasons why restrictions on polygamy should be lifted. First of all, there is so much resistance among polygamous societies against the criminalization that it becomes fruitless to put a ban on it in the first place. Resistance against the law discourages law enforcement officials from charging the violators of law. Since this law is not even upheld as strongly as it should be, it should be removed. Secondly, the fact that it is criminalized makes polygamy impossible to study and regulate. Every single marital institution comes with problems. Regardless of polygamy or monogamy, there are always going to be marriages with domestic abuse, arguments about property rights, infidelity, and arguments about children's rights and childcare. If polygamous marriage is not regulated, the domestic abuse, property rights, infidelity, and childcare problems are similarly going to be left unsolved. To protect the members of marriage, their children, and their property, polygamous marriage should be legalized. Another reason why the ban on polygamy should be lifted is because it unfairly penalizes minorities who practice it for religious reasons. It is an attack on their religion, and the ban is simply unconstitutional. Furthermore, the law that outlines the ban on polygamy outlines it 
implicitly as an absolute liability offense. There is no scope of defense mentioned in the provision. It also violates the principles of fundamental justice.

To conclude it should be restated that polygamy should be legalized in Canada due to its adverse impact on women, children and society as a whole and its inconsistency with the Constitution of Canada. There are some benefits that can be achieved if such a practice is legalized. Legalization of polygamy will protect and uphold fundamental values and principles of Canadian society. It could be an effective way to deal with some growing social problems such as divorce, homelessness, single mother poverty, fatherlessness, domestic violence and

child abuse. Moreover, legalization of polygamy will make the polygamous families and societies visible to the mainstream society and allow the researchers to conduct more researches and generate empirical evidence to develop effective social and legal policies.

\section{Bibliography}

\section{Books:}

Bennion, Janet, Polygamy in Primetime: Media, Gender and Politics in Mormon Fundamentalism, (Massachusetts: Brandies University Press, 2012).

Bourdelois, Béatrice, Mariage polygamique et droit positif français (Paris: GLN Joly Ed, 1993).

Bramham Daphne, The Secret Lives of Saints: Child Brides and Lost Boys in Canada's Polygamous Mormon Sect (Toronto: Random House Canada, 2008). 
Chapman, Samuel, Polygamy, Bigamy and Human Rights Law (United States: Xlibris Corporation 2001).

Dimin, Lee S., Corporatocracy: A Revolution in Progress (Bloomington: iUniverse, 2011).

D P, Barash, , \& J E, Lipton, , The Myth of Monogamy: Fidelity and Infidelity in Animals and People, (New York: Holt Paper Back, 2002).

Embry Jessie L, Mormon Polygamous Families: Life in the Principle (Salt Lake City: University of Utah Press, 1987).

E O, Laumann, J H, Gagnon, R T, Michael, \& S, Michaels, The social organization of sexuality: Sexual practices in the United States (Chicago: University of Chicago Press, 1994).

George, Joyce, Christian Marriage: An Historical and Doctrinal Study (Maryland: Sheed and Ward Books, 2007).

Gordon, Sarah Barringer, The Mormon Question:Polygamy and Constitutional Conflict in Ninteenth Century America (Chapel Hill: University of North Carolina Press, 2002).

Ingoldsby B Bron, Families in Global Canada and Multicultural Perspective (Thousand Oaks, CA: Sage Publications, 2006).

Kufman, Amy J, Bailey Martha, Polygamy in the Monogamous World (California: Praeger, 2010).

Kilbride, L Philip, Page R Douglas, Plural Marriage for Our Time: a Reinvented option 2d ed., (California; Preager, 2012).

Mocheal, Quinn, D., "Mormon Women Have Had the Priesthood since 1843" In Maxine Hanks, eds, Women and Authority: Re-Emerging Mormon Feminism (Salt lake City: Signature Books, 1992).

Peters, Elizabeth, Claire M. Kamp Dus, Marriage and Family: Perspectives and Complexities (New York: Columbia University Press, 2009).

Peter Hogg, Constitutional Law of Canada Student Ed (Toronto: Carswell, 2002).

Peter Hogg, Constitutional Law of Canada Student Ed (Toronto: Carswell, 2006).

Percival AP, Roman Schism Illustrated from the record of the Catholic Church (London: Gilbert and Rivington Printers, 1836).

Sharpe, Robert J, Swinton, Katherine E, Rouch, Kent, The charter of Rights and Freedoms $2^{\text {nd }}$ Ed (Toronto: Irwin Law Inc, 2010). 
Sheppard, Colleen, Inclusive Equality: The Relational Dimensions of Systematic Discrimination in Canada (Quebec: McGill-Queen's University Press, 2010).

Sheff Elizabeth, "Strategies in Polyamorous Parenting”, in M Barker \& D. Langridge (Eds.), Understanding non-monogamies (New York: Routledge, 2010).

Zeitzen, Miriam Koktvedgaard, Polygamy: A Cross-Cultural Analysis, (Oxford: Berg Publisher, 2008).

White, Gregory Mullen, Paul, Jealousy: Theory, Research and Clinical Strategies, (New York: Guilford Press, 1989).

Wayne, Dr Weiten \& McCann, Dr Doug, Psychology: Themes and Variations (Scarborough: Nelson College Indigenous, 2009).

Yamani, Maha A.Z, Polygamy and Law in Contemporary Saudi Arabia (Berkshre: Ithaca press, 2008).

\section{Journal Articles:}

Al-Krenawi, Alean, Graham, John R, "A Comparison of Family Functioning, Life and Marital Satisfaction, and Mental Health of Women in Polygamous and Monogamous Marriages", (2006) 52 IJSP 5.

Amato and Previti "People's Reasons for Divorcing: Gender, Social Class, the Life Course, and Adjustment" (2003) 24 J. Fam. Issues 602.

Arrington, Leonard, "Religion and Economics in Modern History" (1961) 3 BYU Studies 15.

Bala, Nicholas, "Why Canada's Prohibition of Polygamy Is Constitutionally Valid and Sound Social Policy," (2009) 25 Can J Fam L 165.

Campbell, Angela, “Bountiful Voices” (2009) 47Osgoode Hall LJ 183.

Conley Terri D, Ziegler, Ali, Moors, Amy C, Matsick, L Jes, and Brandon Valentine, “A Critical Examination of Popular Assumptions About the Benefits and Outcomes of Monogamous Relationships" 17 Pers Soc Psychol Rev 124.

Chambers, David L., "Polygamy and Same-sex Marriage” (1997) 26 Hofstra LR 53.

Dent, George W, Jr. “How Does Same-sex Marriage Threaten You?” (2006-2007) 59 Rutgers L Rev 233.

Dlamin, CRM, “Should we legalise or abolish polygamy?” (1989), 22 Comp \& Int'l LJ S Afr 330. 
Drummond, Susan, “Polygamy's Inscrutable Criminal Mischief”, (2009) 47 Osgoode Hall LJ 317.

Duncan Emily J, "the positive effects of legalizing polygamy: Love is a many splendid thing" 15 Duke J. Gender L. \& Pol'y (2008).

Kaufman, Amy J, "Polygamous Marriages in Canada" (2005) 21 Can J Fam L 315.

Moller,Valerie and Welch, Gray John, "Polygamy, Economic Security and Well-being of Retired Zulu Migrant Workers" (1990) 5 Journal of Cross-Cultural Gerontology 205.

P R, Amato, \& S J, Rogers, "A Longitudinal Study of Marital Problems and Subsequent Divorce", (1997) 59 J. Marriage Fam 612.

R A L Platt, D P Nalbone, G M Casanova, \& J L Wetchler, "Parental conflict and infidelity as predictors of adult children's attachment style and infidelity" (2008) 36 Am J Fam Ther 149.

S J South, \& K M Lloyd, (1995) Spousal alternatives and marital dissolution 60 Am Sociol Rev 21.

\section{Reports, Policy Papers, Advisory Papers and Government Documents:}

Campbell, Angela, How Have Policy Approaches to Polygamy Responded to Women's Experiences and Rights? An International, Comparative Analysis: Final Report for Status of Women Canada" (Ottawa: Status of Women Canada, 2005). <SSRN: http://ssrn.com/abstract=1360230 or http://dx.doi.org/10.2139/ssrn.1360230>.

Debates of the House of Commons, 6th Parl, 4th Sess, (10 April 1890) (Sir John Thompson), House of Commons, 40th Parl, 3rd Sess, No. 42 (March 26, 2011) (Hedy Fry).

Law Reform Commission of Canada, Bigamy, Working Paper No. 42 (Ottawa: Law Reform Commission of Canada, 1985).

Law and Government Division, Parliamentary Information and Research, Legislative History of Bill C-38 (2 ${ }^{\text {nd }}$ February, 2005) (Mary C. Hurley).

Committee on the Judiciary United States Senate, Crimes Associated with Polygamy: the Need for Coordinated Senate and Federal Response (July 24, 2008) (Chair: Patrick J Leahy).

The Constitutional Question Act, Amicus Curiae [1996] RSBC, c 68, vol 180. 


\section{Newspaper, Dictionary and Online Sources}

4 in 10 1st Marriages end in Divorce: Report", CBC News (4 October 2010) http://www.cbc.ca/news/canada/story/2010/10/04/vanier-study004.html

Anderson, Neil, "Polygamy in Canada: a Case of Double Standard" The Guardian (30 November 2011) http://www.theguardian.com/commentisfree/belief/2011/nov/30/heterosexualitycanada-law-monogamy-polygamy.

Black's Law Dictionary, $2^{\text {nd }}$ ed, sub verbo "adultary" <http://thelawdictionary.org/adultery/\#ixzz2bo5oJGU4>.

Binnie, Ian Justice, "Justice Charles Gonthier and the Unwritten Principles of the Constitution" (A Symposium in Honor of Charles D Gonthier, delivered at the McGill University, May 2021, $2011<$ http://cisdl.org/gonthier/public/pdfs/papers/Confrence_Charles_D_Gonthier__Ian_Binnie.pdf $>$.

Cheating on your spouse and the effect on the resulting children, Online: Canadian Children Rights Council, http://www.canadiancrc.com/Infidelity.aspx.

Fatherlessness is one of the Grates Problems in Canada, Online: Canadian Children Rights Council, <http://www.canadiancrc.com/Fatherlessness/Fatherlessness_in_Canada.aspx >.

Family Violence Laws, Online: Department of Justice < http://www.justice.gc.ca/eng/cj-jp/fvvf/laws-lois.html>.

Infidelity Statistics, Online: Statistics Brain <http://www.statisticbrain.com/infidelity-statistics/> .

Legal Information Institute (August 19, 2010), Online: Cornel University Law School, <http://www.law.cornell.edu/wex/mens_rea>.

Lorenz, W Andrea, “Canada's Pioneer Mosque”, Saudi Aramco Magazine 49 :4 (August 1998) <http://www.saudiaramcoworld.com/issue/199804/canada.s.pioneer.mosque.htm>.

Lee, Felicia R, "Big Love: Real Polygamist Look at HBO Polygamist and Find Sex " The New York Times, (March 28, 2006) <http://www.nytimes.com/2006/03/28/arts/television/28poly.html?pagewanted=all\&_r=0>.

Merriam-Webstar Dictionary, sub verbo "polyamory" < http://www.merriamwebster.com/dictionary/polyamory>. 
Milan, Anne, Marital Status: Overview 2011, Online: Statistics Canada <http://www.statcan.gc.ca/pub/91-209-x/2013001/article/11788-eng.htm>.

Mather, Mark, "US Children in Single-Mother Families" Online: The Population Reference Bureau, <http://www.prb.org/pdf10/single-motherfamilies.pdf >.

\section{Legislation}

An Act for Consolidating and Amending the Statute in this Province relative to Offences Against the Person, Statues of the Province of Canada 1841, c.27, s 22.

Canadian Criminal Code SC 1892, c29, s 278.

Criminal Code, RSC 1985, c C-46.

Morill Anti-Bigamy Act, ch. 126, 12 Stat 501 (1862).

Edmunds-Tucker Act, ch. 397, 24, 24 Stat 635, 639-40 (1887) (repealed 1978).

\section{Jurisprudences}

Blencoe v British Columbia (Human Rights Commission), [2000] 2 SCR 307.

Canada (Attorney General) v Bedford, 2012 ONCA 186 at 412.

Chaoulli v. Quebec (Attorney General), [2005] 1 S.C.R. 791.

Godbout v. Longueuil (City), [1997] 3 SCR 844.

Hyde v Hyde [1866] 1 LRP \& D 130.

Irwin Toy Ltd. v Quebec (Attorney General), [1989] 1 SCR 927.

Law v. Canada (Minister of Employment and Immigration), [1999] 1 S C R 497.

Malette v. Shulman, [1990] 72 OR (2d) 417.

New Brunswick v G (J), [1999] 2 SCR 46.

Reference re: Section 293 of the Criminal Code of Canada, 2011 BCSC 1588.

Re BC Motor Vehicle Act, [1985] 2 SCR 486 
$R v$ City of Sault Ste-Marie [1978] 2 SCR 1299

Rv Big M Drug Mart Ltd.,[1985] 1 SCR 295.

$R$ v Clay, [2003] 3 SCR 735.

$R v$ Oakes [1986] 1 S.C.R. 103.

$R v$ Heywood, [1994] 3 S.C.R. 761.

Rex v Tolhurst and Wright, [1937] OR 570.

Rex v Tolhurst and Wright, [1937] OR 570 at ROWELL CJO.

Rodriguez v. British Columbia (Attorney General), [1993] 3 S.C.R. 519.

Syndicat Northcrest v. Amselem [2004] 2 S.C.R. 55.

Suresh v Canada, [2002] 1 SCR 3.

United States v. Reynolds, 345 U.S. 1 (1953).

United States v. Reynolds, 1 Utah 319 (1876) 145, 162. 